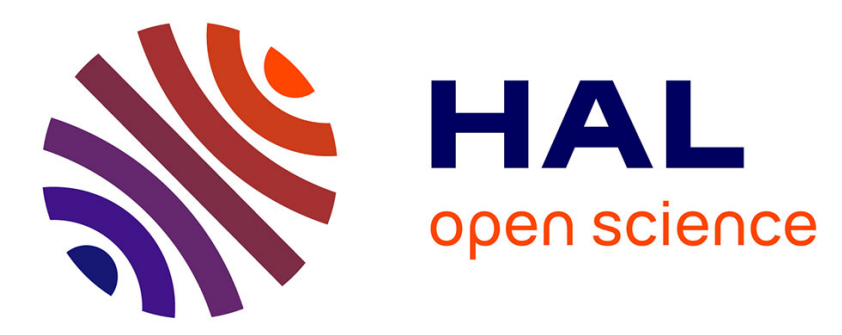

\title{
Fluxional Behaviour of Phosphole and Phosphine Ligands on Triosmium Clusters
}

Yomaira Otero, Deisy Peña, Alejandro Arce, Muriel Hissler, Regis Réau, Ysaura de Sanctis, Edgar Ocando-Mavarez, Rubén Machado, Teresa Gonzalez

\section{- To cite this version:}

Yomaira Otero, Deisy Peña, Alejandro Arce, Muriel Hissler, Regis Réau, et al.. Fluxional Behaviour of Phosphole and Phosphine Ligands on Triosmium Clusters. Journal of Organometallic Chemistry, 2015, 799-800, pp.45-53. 10.1016/j.jorganchem.2015.08.026 . hal-01200616

\section{HAL Id: hal-01200616 \\ https://hal-univ-rennes1.archives-ouvertes.fr/hal-01200616}

Submitted on 2 Dec 2015

HAL is a multi-disciplinary open access archive for the deposit and dissemination of scientific research documents, whether they are published or not. The documents may come from teaching and research institutions in France or abroad, or from public or private research centers.
L'archive ouverte pluridisciplinaire HAL, est destinée au dépôt et à la diffusion de documents scientifiques de niveau recherche, publiés ou non, émanant des établissements d'enseignement et de recherche français ou étrangers, des laboratoires publics ou privés. 
The unsaturated cluster $\left[\mathrm{Os}_{3}(\mu-\mathrm{H})_{2}(\mathrm{CO})_{10}\right]$ reacts with a variety of $\pi$-conjugated phosphole ligands to give mono-substituted derivatives with fluxional behavior, while the reaction of $\left[\mathrm{Os}_{3}(\mathrm{CO})_{10}\left(\mathrm{CH}_{3} \mathrm{CN}\right)_{2}\right]$ with cyanoethyldiphenylphosphine affords mono- and bis(phosphine)substituted clusters, whose dynamic behavior is studied by variable-temperature ${ }^{1} \mathrm{H}$ and ${ }^{31} \mathrm{P}$ NMR spectroscopy. 


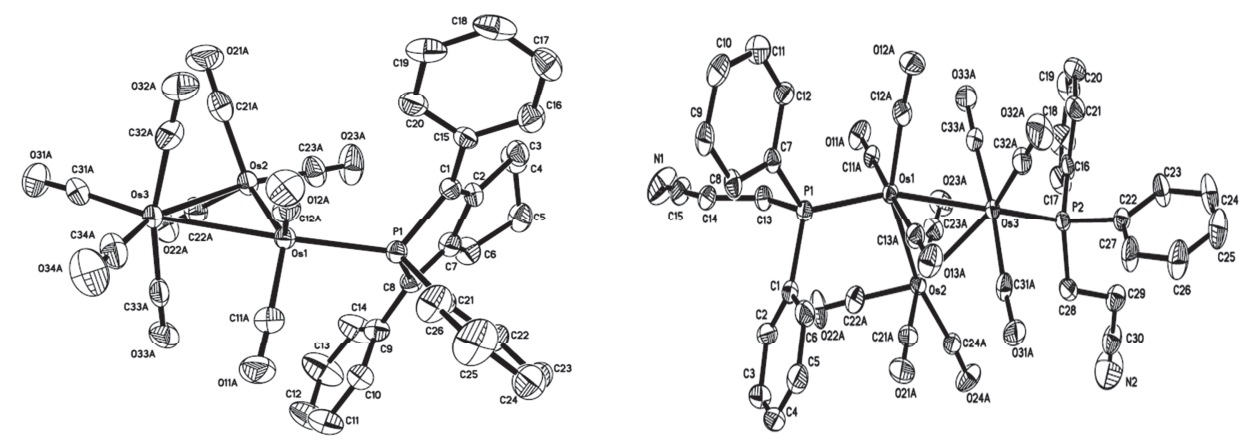




\section{Fluxional Behaviour of Phosphole and Phosphine Ligands on Triosmium Clusters}

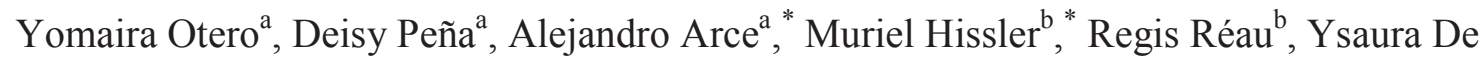
Sanctis ${ }^{\mathrm{a}}$, Edgar Ocando-Mavarez ${ }^{\mathrm{a}}$, Rubén Machado ${ }^{\mathrm{a}}$, Teresa Gonzalez ${ }^{\mathrm{a}}$.

${ }^{a}$ Centro de Química, Instituto Venezolano de Investigaciones Cientificas (IVIC), Apartado 21827, Caracas 1020-A, Venezuela.

${ }^{b}$ Institut des Sciences Chimiques de Rennes, UMR 6226, Université de Rennes 1, 35042 Rennes Cedex, France.

*Corresponding authors: Telephone number: +58 212504 1322. E-mail address: aarce@ivic.gob.ve

Telephone number: +332232357 83. E-mail address: muriel.hissler@univ-rennes1.fr

\section{Abstract}

The unsaturated cluster $\left[\mathrm{Os}_{3}(\mu-\mathrm{H})_{2}(\mathrm{CO})_{10}\right]$ reacts with a variety of $\pi$-conjugated phosphole ligands: 2,5-bis(2-thienyl)-1-phenylphosphole, 2,5-bis(2-pyridyl)-1-phenylphosphole, and 1,2,5triphenylphosphole, to give the monosubstituted $\left[\mathrm{Os}_{3}(\mu-\mathrm{H})(\mathrm{H})(\mathrm{CO})_{10}(\mathrm{P})\right]$ and $\left[\mathrm{Os}_{3}(\mu-\mathrm{H})_{2}(\mathrm{CO})_{9}(\mathrm{P})\right]$ derivatives. Variable-temperature ${ }^{1} \mathrm{H}$ NMR studies for the decacarbonyltriosmium complexes show that the hydride ligands undergo fluxional behavior and its decarbonylation gave the nonacarbonyl unsaturated species with equivalent hydrides. An X-ray crystallographic analysis of $\left[\mathrm{Os}_{3}(\mu-\right.$ $\left.\mathrm{H})_{2}(\mathrm{CO})_{9}(\mathrm{P})\right]$ (2b) $(\mathrm{P}=$ 1,2,5-triphenylphosphole $)$ is reported. From 2,5-bis(2-pyridyl)-1phenylphosphole four isomers are obtained, the ${ }^{1} \mathrm{H}$ NMR spectrum at low temperature indicates that the phosphole ligand may occupy pseudoaxial and equatorial sites at one of the osmium atoms bearing the bridging hydride. The reaction of $\left[\mathrm{Os}_{3}(\mathrm{CO})_{10}\left(\mathrm{CH}_{3} \mathrm{CN}\right)_{2}\right]$ with cyanoethyldiphenylphosphine affords mono- and bis(phosphine)-substituted clusters. The X-ray crystal structure of the monosubstituted $\left[\mathrm{Os}_{3}(\mathrm{CO})_{11}\left(\eta^{1}-\mathrm{PC}_{15} \mathrm{H}_{14} \mathrm{~N}\right)\right](\mathbf{3})$ derivative is discussed. The dynamic behavior observed for $\left[\mathrm{Os}_{3}(\mathrm{CO})_{10}\left(\eta^{1}-\mathrm{PC}_{15} \mathrm{H}_{14} \mathrm{~N}\right)_{2}\right](4)$ is studied by variable-temperature ${ }^{1} \mathrm{H}$ and ${ }^{31} \mathrm{P}\left\{{ }^{1} \mathrm{H}\right\}$ NMR spectroscopy. The latter studies show a mixture of two geometric isomers, 
which are in dynamic equilibrium at room temperature where the 1,2-trans-trans isomer (4a) is favored, whose molecular structure has been determined by X-ray crystallography.

Keywords: Phosphole, phosphine, unsaturated osmium cluster, fluxional behavior, mono- and disubstituted triosmium.

\section{Introduction}

Studies of electronic and coordinative deficiency in mononuclear complexes suggest that unsaturated transition metal clusters should exhibit unique patterns of chemical behavior with potential applications in catalysis [1-5]. The availability of multiple metallic binding sites at the heart of the cluster-surface can be an important factor influencing catalytic activity, occupying a position between traditional heterogeneous and homogeneous systems [6].

Catalytic hydrogenation is one of the most important industrial processes, for which there has been a substantial number of related studies using polymetallic hydride clusters [7]. In this context, the coordinatively unsaturated $46 \mathrm{e}^{-}\left[\mathrm{Os}_{3}(\mu-\mathrm{H})_{2}(\mathrm{CO})_{10}\right]$ cluster has been reported to catalyze olefin isomerization and hydrogenation [8-10]. These unsaturated species readily react with a number of Lewis bases (L), such as phosphines, arsines, $\mathrm{CO}$, nitriles, amines and halides, to give coordinatively saturated $\left[\mathrm{Os}_{3}(\mu-\mathrm{H})(\mathrm{H})(\mathrm{CO})_{10}(\mathrm{~L})\right]$ clusters which have showed intramolecular bridge-terminal hydride exchange $[8,11,12]$. Indeed, the unsaturated $\left[\mathrm{Os}_{3}(\mu-\mathrm{H})_{2}(\mathrm{CO})_{9}(\mathrm{~L})\right]$ clusters are often symmetric and the hydride ligands are chemically equivalent [13, 14].

On the other hand, phosphine-substituted triosmium clusters have always attracted researchers interest not only from a synthetic point of view, but also because of their diverse applications in catalysis [15]. One interesting feature of disubstituted $1,2-\left[\mathrm{Os}_{3}(\mathrm{CO})_{10}(\mathrm{~L})_{2}\right](\mathrm{L}=$ 
phosphine) derivatives is the different isomers that are present, which are in rapid equilibrium and have been detected by variable-temperature ${ }^{31} \mathrm{P}\left\{{ }^{1} \mathrm{H}\right\}$ NMR spectroscopy $[16,17]$.

In view of the importance of triosmium and triruthenium clusters, we have studied its reactivity with heterocyclic phosphines known as phospholes, such as 1-phenylphosphole, 3,4dimethyl-1-phenylphosphole and 3-methyl-1-phenylphosphole [18-20]. Herein, we report the reaction between the unsaturated cluster $\left[\mathrm{Os}_{3}(\mu-\mathrm{H})_{2}(\mathrm{CO})_{10}\right]$ and the $\pi$-conjugated phosphole ligands 2,5-bis(2-thienyl)-1-phenylphosphole, 1,2,5-triphenylphosphole, and 2,5-bis(2-pyridyl)-1phenylphosphole. We also study the reaction of $\left[\mathrm{Os}_{3}(\mathrm{CO})_{10}\left(\mathrm{CH}_{3} \mathrm{CN}\right)_{2}\right]$ with cyanoethyldiphenylphosphine. Most of the triosmium derivatives show dynamic behavior in solution with rapid exchange of the hydride or phosphine ligands.

\section{Results and discussion}

i) Synthesis and Characterization:

Thermal treatment of $\left[\mathrm{Os}_{3}(\mu-\mathrm{H})_{2}(\mathrm{CO})_{10}\right]$ with 2,5-bis(2-thienyl)-1-phenylphosphole,

\section{1,2,5-triphenylphosphole and 2,5-bis(2-pyridyl)-1-phenylphosphole.}

In general, we have found that the binding mode of the $\pi$-conjugated phospholes in the unsaturated $\left[\mathrm{Os}_{3}(\mu-\mathrm{H})_{2}(\mathrm{CO})_{10}\right]$ cluster is restricted to the two-electron typical coordination of a tertiary phosphine, where electronic properties and steric effects of these phospholes must be playing a role in controlling the final product distribution. Thus, 1,2,5-triphenylphosphole reacts very slowly with $\left[\mathrm{Os}_{3}(\mu-\mathrm{H})_{2}(\mathrm{CO})_{10}\right]$ under heating to give only the nonacarbonyl $\left[\mathrm{Os}_{3}(\mu-\right.$ $\left.\mathrm{H})_{2}(\mathrm{CO})_{9}\left(\eta^{1}-\mathrm{PC}_{26} \mathrm{H}_{23}\right)\right]$ (2b) cluster, whereas the reaction with 2,5-bis(2-thienyl)-1phenylphosphole and 2,5-bis(2-pyridyl)-1-phenylphosphole affords the decacarbonyl $\left[\mathrm{Os}_{3}(\mu-\right.$ $\mathrm{H})(\mathrm{H})(\mathrm{CO})_{10}($ phosphole)] clusters, which readily undergo decarbonylation to give the 
corresponding nonacarbonyl $\left[\mathrm{Os}_{3}(\mu-\mathrm{H})_{2}(\mathrm{CO})_{9}\right.$ (phosphole)] compounds. Additionally, it was found that $\left[\mathrm{Os}_{3}(\mu-\mathrm{H})_{2}(\mathrm{CO})_{9}(\mathrm{P})\right][\mathrm{P}=2,5$-bis(2-pyridyl)-1-phenylphosphole $]$ displays a variety of isomers.

Reaction of $\left[\mathrm{Os}_{3}(\mu-\mathrm{H})_{2}(\mathrm{CO})_{10}\right]$ with 2,5-bis(2-thienyl)-1-phenylphosphole in refluxing cyclohexane yielded two compounds characterized as $\left[\mathrm{Os}_{3}(\mu-\mathrm{H})(\mathrm{H})(\mathrm{CO})_{10}\left(\eta^{1}-\mathrm{PC}_{22} \mathrm{H}_{19} \mathrm{~S}_{2}\right)\right](\mathbf{1 a})$ and $\left[\mathrm{Os}_{3}(\mu-\mathrm{H})_{2}(\mathrm{CO})_{9}\left(\eta^{1}-\mathrm{PC}_{22} \mathrm{H}_{19} \mathrm{~S}_{2}\right)\right]$ (2a) (Scheme 1). The $v(\mathrm{CO})$ frequencies for $\mathbf{1 a}$ are characteristic of coordinatively saturated $\left[\mathrm{Os}_{3}(\mu-\mathrm{H})(\mathrm{H})(\mathrm{CO})_{10}(\right.$ phosphine $\left.)\right]$ species $[8,11,12,21]$. Its ${ }^{1} \mathrm{H}$ and ${ }^{13} \mathrm{C}\left\{{ }^{1} \mathrm{H}\right\}$ NMR spectra show very small differences compared to those of the free ligand, suggesting P-bonding of the phosphole. Additionally, the ${ }^{1} \mathrm{H}$ NMR spectrum at room temperature shows two broad hydride signals due to a fluxional process that interchanges the hydride ligand environments. At $-60{ }^{\circ} \mathrm{C}$, the ${ }^{1} \mathrm{H}$ NMR spectrum (Figure 1) contains two hydride resonances at $\delta-10.32$ and 20.08, which are associated to the existence of one bridging and one terminal hydride because of the particularly large chemical shift difference between these two hydride NMR resonances. Thus, on the basis of the NMR parameters (hydride chemical shifts, coupling constants and their relationship to literature precedents $[7,11,12,14,21-24])$ the lower field signal is assigned to a terminal hydride with a hydride-hydride coupling constant of $4.1 \mathrm{~Hz}$, and the higher field resonance to a bridging hydride ligand that additionally shows a $J_{\mathrm{PH}}$ coupling of $11.8 \mathrm{~Hz}$. This indicates that the phosphole ligand occupies an equatorial site $c i s$ to the bridging hydride ligand and the terminal hydride is axially coordinated to a different osmium centre, which is consistent with those found in the literature $[7,11,12,14,21-24]$.

The loss of one CO group from 1a, as the second step of the reaction, gives the nonacarbonyl $\left[\mathrm{Os}_{3}(\mu-\mathrm{H})_{2}(\mathrm{CO})_{9}\left(\eta^{1}-\mathrm{PC}_{22} \mathrm{H}_{19} \mathrm{~S}_{2}\right)\right]$ (2a) compound that shows an IR spectrum similar to coordinatively unsaturated $\left[\mathrm{Os}_{3}(\mu-\mathrm{H})_{2}(\mathrm{CO})_{9}(\right.$ phosphine $\left.)\right]$ clusters, where the phosphole ligand is bonded to an equatorial site [8]. The signals observed in the ${ }^{1} \mathrm{H}$ and ${ }^{13} \mathrm{C}\left\{{ }^{1} \mathrm{H}\right\}$ NMR spectra are consistent with a $\eta^{1}$-coordination of the phosphole ligand. The ${ }^{1} \mathrm{H}$ NMR spectrum also shows one 
hydride resonance at $\delta-10.63$ that integrates for two bridging hydrides with a $J_{\mathrm{PH}}$ coupling of 7.6 $\mathrm{Hz}$, what is indicative of the presence of a cis phosphole ligand. Although this region is usually associated to terminal hydrides in triosmium chemistry, it is known that the signal of the unsaturated Os- $-(\mu-\mathrm{H})_{2}-\mathrm{Os}$ unit could also appear at these chemical shifts values [14, 25].

When $\left[\mathrm{Os}_{3}(\mu-\mathrm{H})_{2}(\mathrm{CO})_{10}\right]$ reacts with 1,2,5-triphenyl-phosphole in refluxing cyclohexane only the coordinatively unsaturated $\left[\mathrm{Os}_{3}(\mu-\mathrm{H})_{2}(\mathrm{CO})_{9}\left(\eta^{1}-\mathrm{PC}_{26} \mathrm{H}_{23}\right)\right]$ (2b) cluster is obtained (Scheme 1). All spectroscopic data (IR and NMR) is very similar to those found for $\mathbf{2 a}$ suggesting that the structures are analogous.

From the reaction of $\left[\mathrm{Os}_{3}(\mu-\mathrm{H})_{2}(\mathrm{CO})_{10}\right]$ with 2,5-bis(2-pyridyl)-1-phenylphosphole, in refluxing cyclohexane, $\left[\mathrm{Os}_{3}(\mu-\mathrm{H})_{2}(\mathrm{CO})_{9}\left(\eta^{1}-\mathrm{PC}_{24} \mathrm{H}_{21} \mathrm{~N}_{2}\right)\right]$ (1c) and four inseparable isomers with chemical formula $\left[\mathrm{Os}_{3}(\mu-\mathrm{H})(\mathrm{H})(\mathrm{CO})_{10}\left(\eta^{1}-\mathrm{PC}_{24} \mathrm{H}_{21} \mathrm{~N}_{2}\right)\right]\left(\mathbf{2} \mathbf{c}^{\mathbf{1 - 4}}\right)$ are formed (Schemes 1 and 2). These compounds were characterized by IR and NMR spectroscopy. The room-temperature ${ }^{1} \mathrm{H}$ NMR spectrum of the mixture shows five broad resonances in the hydride region that suggests a fluxional behavior. This movement is "frozen" out at low temperature where five structural isomers can be detected on the NMR time scale. At $-60{ }^{\circ} \mathrm{C}$ (Figure 2), five different hydride signals are clearly seen, whose assignments were unambiguously established by chemical shifts, coupling constants, ${ }^{1} \mathrm{H}-{ }^{1} \mathrm{H}$ correlations and compared with previously reported results $[7,11,12,14,21-24]$. Thus, the structures shown in Scheme 2 for $\mathbf{1 c}$ and isomers $\mathbf{2} \mathbf{c}^{\mathbf{1 - 4}}$ are the most likely. Compound $\mathbf{1 c}$ shows two hydride signals at $\delta-10.41$ and -15.82 , which are attributed to one terminal and one bridging hydride, respectively, on the basis of the dramatic difference in the hydride chemical shifts, as found for 1a and previously reported compounds $[7,11,12,14,21-24,26]$. Moreover, the $J_{\mathrm{P}-\mathrm{HB}}$ value of $16.2 \mathrm{~Hz}$ suggests in this case that the bridging hydride is trans to the phosphole ligand. Both isomers $\mathbf{2} \mathbf{c}^{1}$ and $\mathbf{2} \mathbf{c}^{2}$ show hydride resonances at $\delta-12.28,-14.20$ and $\delta-12.31,-14.31$, respectively, which are very similar to those found for $\left[\mathrm{Os}_{3}(\mu-\mathrm{H})_{2}(\mathrm{CO})_{9}\left(\mathrm{CNBu}^{t}\right)\right]$, where the $\mathrm{CNBu}^{t}$ 
ligand occupies a pseudoaxial site at one of the osmium atoms in the Os- $(\mu-\mathrm{H})_{2}-\mathrm{Os}$ unit, suggesting similar structures. The hydride resonances appear as doublets of doublets due to the hydridehydride and phosphorus-hydride coupling $\left(\mathbf{2 c}^{1}: J_{\mathrm{H}-\mathrm{H}}=3.5 \mathrm{~Hz}, J_{\mathrm{P}-\mathrm{HB} 1}=16.4 \mathrm{~Hz}, J_{\mathrm{P}-\mathrm{HB} 2}=17.0 \mathrm{~Hz}\right.$; $2 \mathbf{c}^{2}: J_{\mathrm{H}-\mathrm{H}}=3.2 \mathrm{~Hz}, J_{\mathrm{P}-\mathrm{HB} 1}=16.4 \mathrm{~Hz}, J_{\mathrm{P}-\mathrm{HB} 2}=16.9 \mathrm{~Hz}$ ); similar couplings have been reported previously $[7,14,26]$. On the other hand, isomers $2 \mathbf{c}^{3}$ and $\mathbf{2} \mathbf{c}^{4}$ show only one hydride resonance at $\delta$ -15.27 and -15.90 , respectively, characteristic of two different bridging hydride ligands as those found for 2a, $2 \mathbf{b}$ and $\left[\mathrm{Ru}_{3}(\mu-\mathrm{H})_{2}(\mathrm{CO})_{10}(\mathrm{P})\right]\left(\mathrm{P}=\mathrm{PPh}_{3}, \mathrm{PMe}_{2} \mathrm{Ph}, \mathrm{PCy}_{3}\right)[23,24]$. In these cases, the bulky phosphole ligand gives rise to two different isomers $\left(2 c^{3}\right.$ and $\left.2 c^{4}\right)$ due to the restricted rotation around the Os-P bond and the interaction of the hydride and pyridyl rings in the phosphole ligand (Scheme 2). Thus, the isomer $\mathbf{2} \mathbf{c}^{\mathbf{3}}$ displays a "downward" phosphole structure, generating less interaction with the hydride ligands (the hydrides signals are observed at low field); while the "upward" phosphole structure in the isomer $2 \mathrm{c}^{4}$ leads to greater interaction and shifts the hydrides resonances to high field.

\section{Thermal treatment of $\left[\mathrm{Os}_{3}(\mathrm{CO})_{10}\left(\mathrm{CH}_{3} \mathrm{CN}\right)_{2}\right]$ with $\mathrm{Ph}_{2} \mathrm{P}\left(\mathrm{CH}_{2} \mathrm{CH}_{2} \mathrm{CN}\right)$.}

Reaction of $\left[\mathrm{Os}_{3}(\mathrm{CO})_{10}\left(\mathrm{CH}_{3} \mathrm{CN}\right)_{2}\right]$ with cyanoethyldiphenylphosphine in refluxing dichloromethane yielded two substituted compounds, which were identified as $\left[\mathrm{Os}_{3}(\mathrm{CO})_{11}\left(\eta^{1}\right.\right.$ $\left.\left.\mathrm{PC}_{15} \mathrm{H}_{14} \mathrm{~N}\right)\right](3)$ and $\left[\mathrm{Os}_{3}(\mathrm{CO})_{10}\left(\eta^{1}-\mathrm{PC}_{15} \mathrm{H}_{14} \mathrm{~N}\right)_{2}\right]$ (4) (Scheme 3). Their IR spectra in the carbonyl stretching region are similar to those of analogous mono- and bis(phosphine)-substituted triosmium and triruthenium clusters [19, 27-32].

The room-temperature ${ }^{31} \mathrm{P}\left\{{ }^{1} \mathrm{H}\right\}$ NMR spectrum of $\boldsymbol{3}$ shows a signal at $\delta=-10.30 \mathrm{ppm}$, which remains unchanged when the temperature is decreased indicating the presence of one isomer, so the phosphine ligand must adopt one of the less sterically hindered equatorial positions in the cluster, as bulky ligands would normally coordinate. The ${ }^{1} \mathrm{H}$ and ${ }^{13} \mathrm{C}\left\{{ }^{1} \mathrm{H}\right\}$ NMR signals do not show 
significant differences compared to those of the free phosphine, suggesting only P-bonding of the phosphine ligand.

The room-temperature ${ }^{31} \mathrm{P}\left\{{ }^{1} \mathrm{H}\right\}$ NMR spectrum of $\mathbf{4}$ in toluene- $d_{8}$ shows three broad signals at $\delta-9.42,-10.47$ and -14.22 , indicating the presence of more than one derivative chromatographically inseparable. At $-20{ }^{\circ} \mathrm{C}$, the ${ }^{31} \mathrm{P}\left\{{ }^{1} \mathrm{H}\right\}$ NMR display signals assigned to two isomers in approximately 7:3 ratio; the major isomer has two non-equivalent phosphorus nuclei, whereas the minor isomer contains two equivalent phosphines (Figure 3). The inseparable mixture of clusters corresponds to the 1,2-trans-cis and 1,2-trans-trans isomers (cis or trans with respect to the Os-Os bond) (Scheme 3), which frequently occurs as a mixture of isomers in solution with rapid equilibrium [16]. The 1,1- and 1,2-cis-cis isomers are ruled out because they would require significantly higher energy due to steric considerations [30, 33].

ii) Fluxional analysis:

Mutual exchange of the bridging and terminal hydride in $\mathbf{1 a}$ is evident by variabletemperature ${ }^{1} \mathrm{H}$ NMR spectra (Figure 1), being a fluxional process similar to those found for the analogous derivative $\left[\mathrm{Os}_{3}(\mu-\mathrm{H})(\mathrm{H})(\mathrm{CO})_{10}(e q-\mathrm{L})\right]\left(\mathrm{L}=\right.$ phosphine, $\left.\mathrm{CNBu}^{\mathrm{t}}\right)[11,14,34]$. At $20{ }^{\circ} \mathrm{C}$, the hydride resonances disappear completely into the baseline and decomposition occurs before the fast-exchange limit could be observed.

The rate constant $k \mathrm{c}$ and the free energy of activation $\left(\Delta G_{\mathrm{c}}^{\dagger}\right)$ for the hydride interchange in 1a could be estimated from ${ }^{1} \mathrm{H}$ NMR data at the slow-exchange limit (see Table 1 and Figure 1). The bridge $\Rightarrow$ terminal hydride exchange in 1 a occurs at a rate of $10.8 \times 10^{3} \mathrm{~s}^{-1}$, and the $\Delta G_{\mathrm{c}}{ }^{\ddagger}$ was found to be $12.2 \mathrm{kcal} \mathrm{mol}^{-1}$, whose values are close to those reported for similar complexes containing phosphine ligands [11, 34]. 
Variable-temperature ${ }^{1} \mathrm{H}$ NMR spectra shown in the Figure 2 for the $\mathbf{1 c}$ and $\mathbf{2} \mathbf{c}^{\mathbf{1 - 4}}$ mixture give evidence of the dynamic behavior of the hydride ligands in these complexes. The slowexchange limit at $-60{ }^{\circ} \mathrm{C}$ displays eight resonances, which are consistent with the structures previously described (Scheme 2). The formation of $\mathbf{2} \mathbf{c}$ by decarbonylation of $\mathbf{1} \mathbf{c}$ is evidenced with the increasing temperature, where the absence of the hydride signals from $\mathbf{1 c}$ is noticed and, after heating, these signals are not observed again when the sample is measured at room temperature. On the other hand, the hydride signals of isomers $2 \mathbf{c}^{1-4}$ broaden with warming, indicating a faster exchange that coalesces at $85{ }^{\circ} \mathrm{C}$. Additionally, partial decomposition of the sample is evidenced with the presence of new unidentified hydride resonances.

The rate constant $k \mathrm{c}$ and the free energy of activation $\left(\Delta G_{\mathrm{c}}^{+}\right)$for the hydride interchange in 1c and $2 c^{1-4}$ could be estimated in each case from the coalescence temperature and $\Delta v$ at the slowexchange limit (see Table 1). In isomer 1c, the terminal hydride moves into the bridging position at a rate of $6.0 \times 10^{3} \mathrm{~s}^{-1}\left(\Delta G_{\mathrm{c}}^{\dagger}=14.9 \mathrm{kcal} \mathrm{mol}^{-1}\right)$, being a slower dynamic process than in 1a. The interisomer exchange processes for $2 \mathrm{c}^{1-4}$ occurs at rates between $0.7 \times 10^{3} \mathrm{~s}^{-1}$ and $4.0 \times 10^{3} \mathrm{~s}^{-1}$ (Table 1). The estimated $\Delta G_{\mathrm{c}}^{\ddagger}$ values for $\mathbf{2} \mathbf{c}^{3} / \mathbf{2} \mathbf{c}^{1}, \mathbf{2} \mathbf{c}^{3} / \mathbf{2} \mathbf{c}^{2}, \mathbf{2} \mathbf{c}^{4} / \mathbf{2} \mathbf{c}^{1}$ and $\mathbf{2} \mathbf{c}^{4} / \mathbf{2} \mathbf{c}^{2}$ exchange processes are similar, giving an average value of $15.5 \mathrm{kcal} \mathrm{mol}^{-1}$, which is close to that previously reported for analogous clusters containing phosphine ligands, wherein exist equatorial-pseudoaxial exchange processes $[11,26]$. On the other hand, the $\mathbf{2} \mathbf{c}^{\mathbf{3}} / \mathbf{2} \mathbf{c}^{\mathbf{4}}$ and $\mathbf{2} \mathbf{c}^{\mathbf{1}} / \mathbf{2} \mathbf{c}^{\mathbf{2}}$ exchange processes present slightly higher $\Delta G_{\mathrm{c}}^{\ddagger}$ average values (16.4 and $17.1 \mathrm{kcal} \mathrm{mol}^{-1}$, respectively).

As it is observed for compound 4, the three singlet signals displayed in the ${ }^{31} \mathrm{P}\left\{{ }^{1} \mathrm{H}\right\} \mathrm{NMR}$ spectrum (Figure 3 ) at $-20^{\circ} \mathrm{C}$ coalesce when a solution of 4 is warmed to $80{ }^{\circ} \mathrm{C}$. The mechanism of the isomerization has been reported involving a restricted trigonal twist at one of the osmium atoms containing a phosphine ligand $[33,35]$, which results in a movement of the phosphine ligand between the equatorial sites on the metal center (4a and $\mathbf{4 b}$, Scheme 3). The rate constant was 
calculated by the ${ }^{31} \mathrm{P}\left\{{ }^{1} \mathrm{H}\right\} \mathrm{NMR}$ data, $k \mathrm{c}=1.5 \times 10^{3} \mathrm{~s}^{-1}$, and yields a $\Delta G_{\mathrm{c}} \neq$ value of $15.8 \mathrm{kcal} \mathrm{mol}^{-1}$, which is comparable with previous $\Delta G_{\mathrm{c}}^{\ddagger}$ values reported for similar compounds, such as $\left[\mathrm{Os}_{3}(\mathrm{CO})_{10}\left\{\mathrm{P}(\mathrm{OMe})_{3}\right\}_{2}\right][35]$.

iii) X-ray diffraction analysis:

The structure of $\mathbf{2 b}$ was confirmed by an X-ray crystallographic study. A view of the molecule is shown in Figure 4; bond lengths and angles are given in Table 2. The molecular structure consists of an osmium triangle with the phosphole ligand coordinating only via the phosphorus atom, acting as a two electron donor and occupying an equatorial site. Although the hydride ligands were not placed, they certainly bridge Os(1)-Os(2) atoms due to its short bond distance of 2.691(3) A. The other Os-Os distances are slightly shorter than the average metal-metal distance of 2.877(3) $\AA$ for $\left[\mathrm{Os}_{3}(\mathrm{CO})_{12}\right]$ [21], but they are similar to metal-metal distances reported for others 46-electron clusters $[13,36]$. The phosphorus atom coordinates to Os(1) at a distance of 2.355(5) $\AA$, which lies within the range of Os-P bond lengths previously reported [13, 18-20]. The phosphorus atom lies out of the mean plane of the four carbon atoms of the diene moiety by only 0.017(1) $\AA$. The $\mathrm{P}(1)$ and $\mathrm{C}(23 \mathrm{~A})$ atoms are not parallel to the $\mathrm{Os}(1)-\mathrm{Os}(2)$ bond probably due to steric effects, the angles $\mathrm{Os}(2)-\mathrm{Os}(1)-\mathrm{P}(1)$ and $\mathrm{Os}(1)-\mathrm{Os}(2)-\mathrm{C}(23 \mathrm{~A})$ are $104.8(1)^{\circ}$ and $110.0(5)^{\circ}$, respectively.

The structure of $\mathbf{3}$ is shown in Figure 5; selected bond lengths and angles are given in Table 3. The phosphine ligand is coordinated through the phosphorus atom occupying a sterically preferred equatorial site in the triangular metal cluster. The cis $\operatorname{Os}(1)-\mathrm{Os}(2)$ bond $[2.9205(18) \AA]$ to the phosphine ligand is slightly longer than that found for the trans $\mathrm{Os}(2)-\mathrm{Os}(3)[2.886(2) \AA]$ and the remote $\operatorname{Os}(1)-\mathrm{Os}(3)[2.8950(18) \AA]$ bonds. The lengthening of the Os(1)-Os(2) bond may be attributed to both steric and electronic factors, as has been previously found for analogous 
$\left[\mathrm{Os}_{3}(\mathrm{CO})_{11} \mathrm{PR}_{3}\right]$ clusters. The $\mathrm{Os}(2)-\mathrm{P}(1)$ bond length $[2.349(6) \AA]$ is very similar to those reported for related complexes [17, 37-39].

The single crystals of 4 were obtained by slow concentration in acetonitrile, which only corresponded to the isomer $\mathbf{4 a}$. The molecular structure of $\mathbf{4 a}$ is shown in Figure 6; selected bond lengths and angles are listed in Table 3. The single-crystal X-ray structure represents the symmetric isomer 1,2-trans-trans, where the phosphine ligands occupy equatorial coordination sites. The osmium cluster has ten carbonyl ligands, four bonded to Os(2) and three to Os(1) and Os(3). The average Os-Os distance $[2.8913 \AA]$ and the Os(1)-P(1) [2.355(2) $\AA]$, Os(3)-P(2) [2.340(2) $\AA]$ are as expected and close to those reported for $\left[\mathrm{Os}_{3}(\mathrm{CO})_{10}\left(\mathrm{PPh}_{3}\right)_{2}\right]$ [16] and $\left[\mathrm{Os}_{3}(\mathrm{CO})_{10}\left\{\mathrm{Ph}_{2} \mathrm{P}\left(\mathrm{C}_{4} \mathrm{H}_{3} \mathrm{~S}\right)\right\}_{2}\right]$ [30]. The phosphorus atoms are deviated from the metal-metal axis $\left[\mathrm{P}(1)-\mathrm{Os}(1)-\mathrm{Os}(3)=163.35(5)^{\circ}, \mathrm{P} 2-\mathrm{Os} 3-\mathrm{Os} 1=164.98(5)^{\circ}\right]$ due to steric repulsions between the carbonyl groups and the phosphorus atoms.

\section{Conclusions}

$$
\left[\mathrm{Os}_{3}(\mu-\mathrm{H})(\mathrm{H})(\mathrm{CO})_{10}(\mathrm{P})\right] \quad(\mathbf{1}) \text { and }\left[\mathrm{Os}_{3}(\mu-\mathrm{H})_{2}(\mathrm{CO})_{9}(\mathrm{P})\right] \quad(\mathbf{2}) \quad[\mathrm{P}=\text { 2,5-bis(2-thienyl)-1- }
$$

phenylphosphole (a), 1,2,5-triphenylphosphole (b), and 2,5-bis(2-pyridyl)-1-phenylphosphole (c)] clusters were synthesized by reacting $\left[\mathrm{Os}_{3}(\mu-\mathrm{H})_{2}(\mathrm{CO})_{10}\right]$ with the corresponding phosphole derivatives. Terminal and bridging hydrides in $\left[\mathrm{Os}_{3}(\mu-\mathrm{H})(\mathrm{H})(\mathrm{CO})_{10}(\mathrm{P})\right][\mathrm{P}=2,5$-bis $(2$-thienyl)-1phenylphosphole (1a), and 2,5-bis(2-pyridyl)-1-phenylphosphole (1c)] clusters are fluxional and they could be distinguished on the NMR time scale. $\left[\mathrm{Os}_{3}(\mu-\mathrm{H})_{2}(\mathrm{CO})_{9}(\mathrm{P})\right][\mathrm{P}=2,5$-bis(2-thienyl)-1phenylphosphole (2a), and 1,2,5-triphenylphosphole (2b)] clusters show two equivalent bridging hydrides with no fluxional behavior, but $\left[\mathrm{Os}_{3}(\mu-\mathrm{H})_{2}(\mathrm{CO})_{9}\left(\eta^{1}-\mathrm{PC}_{24} \mathrm{H}_{21} \mathrm{~N}_{2}\right)\right]$ (2c) gives rise to four different isomers observed by ${ }^{1} \mathrm{H}$ NMR at low temperature. From the reaction of $\left[\mathrm{Os}_{3}(\mathrm{CO})_{10}\left(\mathrm{CH}_{3} \mathrm{CN}\right)_{2}\right]$ with cyanoethyldiphenylphosphine, mono- and disubstituted clusters are 
obtained. The variable-temperature ${ }^{1} \mathrm{H}$ and ${ }^{31} \mathrm{P}\left\{{ }^{1} \mathrm{H}\right\}$ NMR spectra of the disubstituted 1,2$\left[\mathrm{Os}_{3}(\mathrm{CO})_{10}\left(\eta^{1}-\mathrm{PC}_{15} \mathrm{H}_{14} \mathrm{~N}\right)_{2}\right]$ cluster (4) display a mixture of two isomers (1,2-trans-trans and 1,2trans-cis), which present a dynamic behavior in solution.

\section{Experimental Section}

General Remarks: $\quad\left[\mathrm{Os}_{3}(\mu-\mathrm{H})_{2}(\mathrm{CO})_{10}\right], \quad\left[\mathrm{Os}_{3}(\mathrm{CO})_{10}\left(\mathrm{CH}_{3} \mathrm{CN}\right)_{2}\right], \quad$ 2,5-bis(2-thienyl)-1phenylphosphole, 2,5-bis(2-pyridyl)-1-phenylphosphole, 1,2,5-triphenylphosphole and cyanoethyldiphenylphosphine were synthesized as previously described [40-45]. [Oss $\left.(\mathrm{CO})_{12}\right]$ was used as supplied by Aldrich Chemical Company. ${ }^{1} \mathrm{H},{ }^{13} \mathrm{C}$ and ${ }^{31} \mathrm{P}$ NMR spectra were recorded using Bruker Avance AM300, AM500 and AM600 spectrometers, and assignment of carbon chemical shifts was based on HMBC and HMQC experiments. IR spectra were recorded on a Nicolet 5DXC and single-crystal X-ray data collection was performed at room temperature on a Rigaku AFC7S diffractometer (Mo-K $\alpha$ radiation, $\lambda=0.71073 \AA$ ).

Reaction of $\left[\mathrm{Os}_{3}(\mu-\mathrm{H})_{2}(\mathrm{CO})_{10}\right]$ with 2,5-bis(2-thienyl)-1-phenylphosphole: A solution of $\left[\mathrm{Os}_{3}(\mu-\mathrm{H})_{2}(\mathrm{CO})_{10}\right](100 \mathrm{mg}, 0.173 \mathrm{mmol})$ and 2,5-bis(2-thienyl)-1-phenylphosphole (44 mg, 0.173 mmol) in dry cyclohexane $(50 \mathrm{~mL})$ was taken to reflux under nitrogen for $3.5 \mathrm{~h}$. After evaporation of the solvent, TLC $\left(\mathrm{SiO}_{2}\right)$ of the brown residue (hexane/dichloromethane, 9:1 v/v) gave two compounds $\left[\mathrm{Os}_{3}(\mu-\mathrm{H})(\mathrm{H})(\mathrm{CO})_{10}\left(\eta^{1}-\mathrm{PC}_{22} \mathrm{H}_{19} \mathrm{~S}_{2}\right)\right]$ (1a) $(20 \%$ yield $)$ and $\left[\mathrm{Os}_{3}(\mu-\mathrm{H})_{2}(\mathrm{CO})_{9}\left(\eta^{1}-\right.\right.$

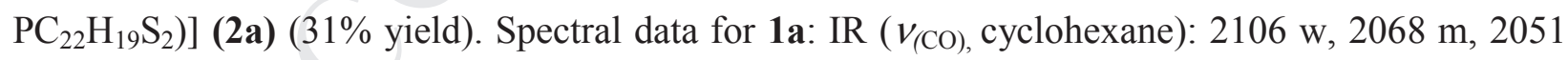
m, 2024 s, 2009 sh, 1999 w, 1982 w, $1969 \mathrm{w} \mathrm{cm}^{-1}$. ${ }^{1} \mathrm{H}$ NMR $\left(500 \mathrm{MHz}, \mathrm{CD}_{2} \mathrm{Cl}_{2}\right), \mathrm{T}=20{ }^{\circ} \mathrm{C}: \delta=$ $1.90\left(\mathrm{~m}, 4 \mathrm{H}, \mathrm{CH}_{2}-\mathrm{CH}_{2}-\mathrm{C}=\mathrm{C}\right), 2.99\left(\mathrm{~m}, 4 \mathrm{H}, \mathrm{CH}_{2}-\mathrm{C}=\mathrm{C}\right), 6.80\left(\mathrm{dd},{ }^{3} \mathrm{~J}_{\mathrm{H} 4-\mathrm{H} 3}=3.6 \mathrm{~Hz},{ }^{4} J_{\mathrm{H} 5-\mathrm{H} 3}=2.4 \mathrm{~Hz}\right.$, $2 \mathrm{H}, \mathrm{H}_{3}$ thienyl) $6.94\left(\mathrm{dd},{ }^{3} J_{\mathrm{H} 5-\mathrm{H} 4}=4.5 \mathrm{~Hz},{ }^{3} J_{\mathrm{H} 3-\mathrm{H} 4}=3.6 \mathrm{~Hz}, 2 \mathrm{H}, \mathrm{H}_{4}\right.$ thienyl $), 7.32\left(\mathrm{dd},{ }^{3} J_{\mathrm{H} 4-\mathrm{H} 5}=4.5 \mathrm{~Hz}\right.$, ${ }^{4} J_{\mathrm{H} 3-\mathrm{H} 5}=2.4 \mathrm{~Hz}, 2 \mathrm{H}, \mathrm{H}_{5}$ thienyl $), 7.57\left(\mathrm{~m}, 3 \mathrm{H}, m-/ p-\mathrm{H}_{P h}\right), 7.67\left(\mathrm{dd},{ }^{3} J_{\mathrm{P}-\mathrm{Ho}}=12.6 \mathrm{~Hz},{ }^{4} J_{\mathrm{H} m-\mathrm{Ho}}=7.4 \mathrm{~Hz}\right.$, $\left.2 \mathrm{H}, o-\mathrm{H}_{P h}\right) ; \mathrm{T}=-60{ }^{\circ} \mathrm{C}:-10.32\left(\mathrm{~d},{ }^{2} J_{\mathrm{HB}-\mathrm{HT}}=4.1 \mathrm{~Hz}, \mathrm{H}_{\mathrm{T}}\right),-20.08\left(\mathrm{dd},{ }^{2} J_{\mathrm{P}-\mathrm{HB}}=11.8 \mathrm{~Hz},{ }^{2} J_{\mathrm{HT}-\mathrm{HB}}=4.1\right.$ 
$\left.\mathrm{Hz}, \mathrm{H}_{\mathrm{B}}\right) .{ }^{31} \mathrm{P}\left\{{ }^{1} \mathrm{H}\right\}$ NMR $\left(300 \mathrm{MHz}, \mathrm{CDCl}_{3}, 20{ }^{\circ} \mathrm{C}\right): \delta=+8.30$ (s). Spectral data for $2 \mathrm{a}: \mathrm{IR}\left(v_{(\mathrm{CO})}\right.$, cyclohexane): 2091 m, 2052 s, 2012 s, 1990 w, 1983 m, 1974 w, 1959 w. ${ }^{1}$ H NMR (500 MHz, $\left.\mathrm{CD}_{2} \mathrm{Cl}_{2}\right): \delta=1.88\left(\mathrm{~m}, 4 \mathrm{H}, \mathrm{CH}_{2}-\mathrm{CH}_{2}-\mathrm{C}=\mathrm{C}\right), 3.01\left(\mathrm{~m}, 4 \mathrm{H}, \mathrm{CH}_{2}-\mathrm{C}=\mathrm{C}\right), 6.89\left(\mathrm{~d},{ }^{3} J_{\mathrm{H} 4-\mathrm{H} 3}=4.1 \mathrm{~Hz}, 2 \mathrm{H}\right.$, $\left.\mathrm{H}_{3 \text { thienyl }}\right), 6.98\left(\mathrm{dd},{ }^{3} J_{\mathrm{H} 5-\mathrm{H} 4}=4.4 \mathrm{~Hz},{ }^{3} J_{\mathrm{H} 3-\mathrm{H} 4}=4.1 \mathrm{~Hz}, 2 \mathrm{H}, \mathrm{H}_{4}\right.$ thienyl $), 7.34\left(\mathrm{~d},{ }^{3} J_{\mathrm{H} 4-\mathrm{H} 5}=4.4 \mathrm{~Hz}, 2 \mathrm{H}, \mathrm{H}_{5}\right.$ thienyl), $7.58\left(\mathrm{~m}, 3 \mathrm{H}, m-/ p-\mathrm{H}_{P h}\right), 7.80\left(\mathrm{ddd},{ }^{3} J_{\mathrm{P}-\mathrm{Ho}}=12.3 \mathrm{~Hz},{ }^{3} J_{\mathrm{H} m-\mathrm{Ho}}=8.0 \mathrm{~Hz},{ }^{4} J_{\mathrm{H} p-\mathrm{Ho}}=1.5 \mathrm{~Hz}, 2 \mathrm{H}\right.$, $\left.o-\mathrm{H}_{P h}\right),-10.63\left(\mathrm{~d},{ }^{2} J_{\mathrm{P}-\mathrm{HB}}=7.6 \mathrm{~Hz}, \mathrm{H}_{\mathrm{B}}\right) .{ }^{13} \mathrm{C}\left\{{ }^{1} \mathrm{H}\right\} \mathrm{NMR}\left(500 \mathrm{MHz}, \mathrm{CD}_{2} \mathrm{Cl}_{2}\right): \delta=22.25\left(\mathrm{~s}, \mathrm{CH}_{2}-\mathrm{CH}_{2}-\right.$ $\mathrm{C}=\mathrm{C}), 27.18\left(\mathrm{~d},{ }^{3} J_{\mathrm{P}-\mathrm{C}}=8.2 \mathrm{~Hz}, \mathrm{CH}_{2}-\mathrm{C}=\mathrm{C}\right), 126.56\left(\mathrm{~s}, \mathrm{C}_{5}\right.$ thienyl $), 127.05\left(\mathrm{~s}, \mathrm{C}_{4}\right.$ thienyl $), 127.55\left(\mathrm{~d},{ }^{3} J_{\mathrm{P}-\mathrm{C}}\right.$ $\left.=5.6 \mathrm{~Hz}, \mathrm{C}_{3 \text { thienyl }}\right), 128.71\left(\mathrm{~d},{ }^{3} J_{\mathrm{P}-\mathrm{C}}=48.1 \mathrm{~Hz}, m-\mathrm{C}_{P h}\right), 129.37\left(\mathrm{~d},{ }^{4} J_{\mathrm{P}-\mathrm{C}}=11.0 \mathrm{~Hz}, p-\mathrm{C}_{P h}\right), 131.79$ $\left(\mathrm{d},{ }^{l} J_{\mathrm{P}-\mathrm{C}}=1.6 \mathrm{~Hz}\right.$, ipso- $\left.\mathrm{C}_{P h}\right), 132.66\left(\mathrm{~d},{ }^{2} J_{\mathrm{P}-\mathrm{C}}=12.0 \mathrm{~Hz}, o-\mathrm{C}_{P h}\right), 135.39\left(\mathrm{~d},{ }^{l} J_{\mathrm{P}-\mathrm{C}}=50.2 \mathrm{~Hz}, \mathrm{C}_{\alpha}\right)$, $135.59\left(\mathrm{~d},{ }^{2} J_{\mathrm{P}-\mathrm{C}}=17.3 \mathrm{~Hz}, \mathrm{C}_{2}\right.$ thienyl), $147.87\left(\mathrm{~d},{ }^{2} J_{\mathrm{P}-\mathrm{C}}=13.5 \mathrm{~Hz}, \mathrm{C}_{\beta}\right), 184.38-176.10$ (M-CO). ${ }^{31} \mathrm{P}\left\{{ }^{1} \mathrm{H}\right\}$ NMR $\left(300 \mathrm{MHz}, \mathrm{CDCl}_{3}\right): \delta=+38.90(\mathrm{~s})$.

Reaction of $\left[\mathrm{Os}_{3}(\mu-\mathrm{H})_{2}(\mathrm{CO})_{10}\right]$ with 1,2,5-triphenylphosphole: A solution of $\left[\mathrm{Os}_{3}(\mu-\mathrm{H})_{2}\right.$ $\left.(\mathrm{CO})_{10}\right](100 \mathrm{mg}, 0.173 \mathrm{mmol})$ and 1,2,5-triphenylphosphole (43 $\left.\mathrm{mg}, 0.173 \mathrm{mmol}\right)$ in dry cyclohexane $(50 \mathrm{~mL})$ was taken to reflux under nitrogen for $5 \mathrm{~h}$. After evaporation of the solvent, TLC $\left(\mathrm{SiO}_{2}\right)$ of the brown residue (hexane/dichloromethane, 9:1 v/v) gave $\left[\mathrm{Os}_{3}(\mu-\mathrm{H})_{2}(\mathrm{CO})_{9}\left(\eta^{1}-\right.\right.$ $\left.\mathrm{PC}_{26} \mathrm{H}_{23}\right)$ ] (2b) (53\% yield). Spectral data for $\mathbf{2 b}$ : IR ( $v_{(\mathrm{CO})}$, cyclohexane): $2090 \mathrm{~m}, 2052 \mathrm{~s}, 2012 \mathrm{~s}$, 1990 m, 1981 m, 1973 m, 1960 w. ${ }^{1} \mathrm{H}$ NMR (500 MHz, $\left.\mathrm{CD}_{2} \mathrm{Cl}_{2}\right): \delta=1.80$ (m, 4H, $\left.\mathrm{CH}_{2}-\mathrm{CH}_{2}-\mathrm{C}=\mathrm{C}\right)$, $2.86\left(\mathrm{~m}, 4 \mathrm{H}, \mathrm{CH} \mathrm{H}_{2} \mathrm{C}=\mathrm{C}\right), 7.03\left(\mathrm{dd},{ }^{3} J_{\mathrm{H} 3-\mathrm{H} 2}=7.9 \mathrm{~Hz},{ }^{4} J_{\mathrm{H} 4-\mathrm{H} 2}=2.6 \mathrm{~Hz}, 4 \mathrm{H}, \mathrm{H}_{2}\right.$ phenyl $), 7.25\left(\mathrm{~d},{ }^{3} J_{\mathrm{H} 2-\mathrm{H} 3}=\right.$ $\left.7.9 \mathrm{~Hz}, 4 \mathrm{H}, \mathrm{H}_{3 \text { phenyl }}\right), 7.25\left(\mathrm{~d},{ }^{3} J_{\mathrm{H} 2-\mathrm{H} 4}=2.6 \mathrm{~Hz}, 4 \mathrm{H}, \mathrm{H}_{4}\right.$ phenyl $), 7.58\left(\mathrm{~m}, 3 \mathrm{H}, m-/ p-\mathrm{H}_{P h}\right), 7.80\left(\mathrm{ddd},{ }^{3} J_{\mathrm{P}-}\right.$ $\left.\mathrm{Ho}=11.2 \mathrm{~Hz},{ }^{3} J_{\mathrm{H} m-\mathrm{H} o}=8.0 \mathrm{~Hz},{ }^{4} J_{\mathrm{H} p-\mathrm{Ho}}=4.0 \mathrm{~Hz}, 2 \mathrm{H}, o-\mathrm{H}_{P h}\right),-10,84\left(\mathrm{~d},{ }^{2} J_{\mathrm{P}-\mathrm{HB}}=6.9 \mathrm{~Hz}, \mathrm{H}_{\mathrm{B}}\right)$. ${ }^{13} \mathrm{C}\left\{{ }^{1} \mathrm{H}\right\}$ NMR $\left(500 \mathrm{MHz}, \mathrm{CD}_{2} \mathrm{Cl}_{2}\right): \delta=22.96\left(\mathrm{~s}, \mathrm{CH}_{2}-\mathrm{CH}_{2}-\mathrm{C}=\mathrm{C}\right), 28.43\left(\mathrm{~d},{ }^{3} J_{\mathrm{P}-\mathrm{C}}=8.4 \mathrm{~Hz}, \mathrm{CH}_{2}-\right.$ $\mathrm{C}=\mathrm{C}), 128.07$ (s, $\mathrm{C}_{4}$ phenyl $), 128.59\left(\mathrm{~d},{ }^{l} J_{\mathrm{P}-\mathrm{C}}=46.1 \mathrm{~Hz}\right.$, ipso- $\left.\mathrm{C}_{P h}\right), 128.72\left(\mathrm{~s}, \mathrm{C}_{3}\right.$ phenyl $), 128.75\left(\mathrm{~s}, \mathrm{C}_{2}\right.$ phenyl), $129.78\left(\mathrm{~s}, m-\mathrm{C}_{P h}\right), 132.04\left(\mathrm{~s}, p-\mathrm{C}_{P h}\right), 133.32\left(\mathrm{~d},{ }^{2} J_{\mathrm{P}-\mathrm{C}}=11.8 \mathrm{~Hz}, o-\mathrm{C}_{P h}\right), 134.57\left(\mathrm{~d},{ }^{2} J_{\mathrm{P}-\mathrm{C}}=\right.$ 
$\left.13.8 \mathrm{~Hz}, \mathrm{C}_{1 \text { phenyl }}\right), 141.57\left(\mathrm{~d},{ }^{1} J_{\mathrm{P}-\mathrm{C}}=48.3 \mathrm{~Hz}, \mathrm{C}_{\alpha}\right), 148.69\left(\mathrm{~d},{ }^{2} J_{\mathrm{P}-\mathrm{C}}=14.5 \mathrm{~Hz}, \mathrm{C}_{\beta}\right), 184.89-176.62$ (M-CO). ${ }^{31} \mathrm{P}\left\{{ }^{1} \mathrm{H}\right\}$ NMR (300 MHz, $\left.\mathrm{CDCl}_{3}\right): \delta=+42.69$ (s).

Reaction of $\left[\mathrm{Os}_{3}(\mu-\mathrm{H})_{2}(\mathrm{CO})_{10}\right]$ with 2,5-bis(2-pyridyl)-1-phenylphosphole: A solution of $\left[\mathrm{Os}_{3}(\mu-\mathrm{H})_{2}(\mathrm{CO})_{10}\right](100 \mathrm{mg}, 0.173 \mathrm{mmol})$ and 2,5-bis(2-pyridyl)-1-phenylphosphole (42 mg, 0.173 $\mathrm{mmol})$ in dry cyclohexane $(50 \mathrm{~mL})$ was taken to reflux under nitrogen for $2 \mathrm{~h}$. After evaporation of the solvent, TLC $\left(\mathrm{SiO}_{2}\right)$ of the green residue as above gave one band characterized as $\left[\mathrm{Os}_{3}(\mu-\right.$ $\left.\mathrm{H})(\mathrm{H})(\mathrm{CO})_{10}\left(\eta^{1}-\mathrm{PC}_{24} \mathrm{H}_{21} \mathrm{~N}_{2}\right)\right](\mathbf{1 c})$ and four isomers $\left[\mathrm{Os}_{3}(\mu-\mathrm{H})_{2}(\mathrm{CO})_{9}\left(\eta^{1}-\mathrm{PC}_{24} \mathrm{H}_{21} \mathrm{~N}_{2}\right)\right]\left(\mathbf{2} \mathbf{c}^{\mathbf{1 - 4}}\right) \quad(50 \%$ yield) which are inseparable chromatographically. Spectral data for 1-2: IR ( $v_{(\mathrm{CO})}$, cyclohexane): 2108 w, 2096 w, 2071 m, 2058 w, 2047 m, 2038 s, 2019 m, 1995 s, 1986 m, 1969 w, 1957 m cm$^{-1}$. ${ }^{1} \mathrm{H}$ NMR $\left(500 \mathrm{MHz}, \mathrm{CD}_{2} \mathrm{Cl}_{2}\right), \mathrm{T}=20{ }^{\circ} \mathrm{C}: \delta=1.65\left(\mathrm{~m}, 4 \mathrm{H}, \mathrm{CH}_{2}-\mathrm{CH}_{2}-\mathrm{C}=\mathrm{C}\right), 1.90\left(\mathrm{~m}, 4 \mathrm{H}, \mathrm{CH}_{2}-\mathrm{CH}_{2}-\right.$ $\mathrm{C}=\mathrm{C}), 2.88\left(\mathrm{~m}, 4 \mathrm{H}, \mathrm{CH}_{2}-\mathrm{C}=\mathrm{C}\right), 3.09\left(\mathrm{~m}, 4 \mathrm{H}, \mathrm{CH} \mathrm{H}_{2} \mathrm{C}=\mathrm{C}\right), 6.96\left(\mathrm{ddd},{ }^{3} J_{\mathrm{H} 4-\mathrm{H} 5}=6.9 \mathrm{~Hz},{ }^{3} J_{\mathrm{H} 6-\mathrm{H} 5}=3.7\right.$ $\mathrm{Hz},{ }^{4} J_{\mathrm{H} 3-\mathrm{H} 5}=1.2 \mathrm{~Hz}, 2 \mathrm{H}, \mathrm{H}_{5}$ pyridyl $), 7.27\left(\mathrm{~m}, 3 \mathrm{H}, m-/ p-\mathrm{H}_{P h}\right), 7.36\left(\mathrm{~m}, 2 \mathrm{H}, o-\mathrm{H}_{P h}\right), 7.71\left(\mathrm{dd},{ }^{3} J_{\mathrm{H} 4-\mathrm{H} 3}=\right.$ $8.4 \mathrm{~Hz},{ }^{4} J_{\mathrm{H} 5-\mathrm{H} 3}=1.2 \mathrm{~Hz}, 2 \mathrm{H}, \mathrm{H}_{3}$ pyridyl $), 7.81\left(\mathrm{dd},{ }^{3} J_{\mathrm{H} 3-\mathrm{H} 4}=8.4 \mathrm{~Hz},{ }^{3} J_{\mathrm{H} 5-\mathrm{H} 4}=6.9 \mathrm{~Hz}, 2 \mathrm{H}, \mathrm{H}_{4}\right.$ pyridyl $)$, $8.63\left(\mathrm{~d},{ }^{3} J_{\mathrm{H} 5-\mathrm{H} 6}=3.7 \mathrm{~Hz}, 2 \mathrm{H}, \mathrm{H}_{6}\right.$ pyridyl $), 8.77\left(\mathrm{~d},{ }^{3} J_{\mathrm{H} 5-\mathrm{H} 6}=3.7 \mathrm{~Hz}, 2 \mathrm{H}, \mathrm{H}_{6}\right.$ pyridyl $), 8.80\left(\mathrm{~d},{ }^{3} J_{\mathrm{H} 5-\mathrm{H} 6}=\right.$ $\left.3.8 \mathrm{~Hz}, 2 \mathrm{H}, \mathrm{H}_{6 \text { pyridyl }}\right), 8.83\left(\mathrm{~d},{ }^{3} J_{\mathrm{H} 5-\mathrm{H} 6}=5.3 \mathrm{~Hz}, 2 \mathrm{H}, \mathrm{H}_{6}\right.$ pyridyl $) ; \mathrm{T}=-60{ }^{\circ} \mathrm{C}:-10.41\left(\mathrm{~d},{ }^{2} J_{\mathrm{HB}-\mathrm{HT}}=3.5\right.$ $\left.\mathrm{Hz}, \mathrm{H}_{\mathrm{T}(\mathbf{1} \mathbf{c})}\right),-12.28\left(\mathrm{dd},{ }^{2} J_{\mathrm{P}-\mathrm{HB} 1}=16.4 \mathrm{~Hz},{ }^{2} J_{\mathrm{B} 2-\mathrm{B} 1}=3.5 \mathrm{~Hz}, \mathrm{H}_{\mathrm{B} 1(\mathbf{2 c 1})}\right),-12.31\left(\mathrm{dd},{ }^{2} J_{\mathrm{P}-\mathrm{HB} 1}=16.4 \mathrm{~Hz}\right.$, $\left.{ }^{2} J_{\mathrm{B} 1-\mathrm{B} 2}=3.2 \mathrm{~Hz}, \mathrm{H}_{\mathrm{B} 1(\mathbf{2 c} 2)}\right),-14.20\left(\mathrm{dd},{ }^{2} J_{\mathrm{P}-\mathrm{HB} 2}=17.0 \mathrm{~Hz},{ }^{2} J_{\mathrm{B} 1-\mathrm{B} 2}=3.5 \mathrm{~Hz}, \mathrm{H}_{\mathrm{B} 2(\mathbf{2 c} \mathbf{c})}\right),-14.31\left(\mathrm{dd},{ }^{2} J_{\mathrm{P}-}\right.$ $\left.\mathrm{HB}_{2}=16.9 \mathrm{~Hz},{ }^{2} J_{\mathrm{B} 1-\mathrm{B} 2}=3.2 \mathrm{~Hz}, \mathrm{H}_{\mathrm{B} 2(\mathbf{2} \mathbf{c})}\right),-15.27\left(\mathrm{~d},{ }^{2} J_{\mathrm{P}-\mathrm{HB}}=34.3 \mathrm{~Hz}, \mathrm{H}_{\mathrm{B}(\mathbf{2} \mathbf{c} 3)}\right),-15.82\left(\mathrm{dd},{ }^{2} J_{\mathrm{P}-\mathrm{HB}}=\right.$ $\left.16.2 \mathrm{~Hz},{ }^{2} J_{\mathrm{HT}-\mathrm{HB}}=3.5 \mathrm{~Hz}, \mathrm{H}_{\mathrm{B}(\mathbf{1 c})}\right),-15.90\left(\mathrm{~d},{ }^{2} J_{\mathrm{P}-\mathrm{HB}}=33.2 \mathrm{~Hz}, \mathrm{H}_{\mathrm{B}(\mathbf{2} \mathbf{c})}\right) .{ }^{31} \mathrm{P}\left\{{ }^{1} \mathrm{H}\right\} \mathrm{NMR}(300 \mathrm{MHz}$, $\left.\mathrm{CDCl}_{3}, 20^{\circ} \mathrm{C}\right): \delta=+27.62(\mathrm{~s})$.

Reaction of $\left[\mathrm{Os}_{3}(\mathrm{CO})_{10}\left(\mathrm{CH}_{3} \mathrm{CN}\right)_{2}\right]$ with cyanoethyldiphenylphosphine: A solution of $\left[\mathrm{Os}_{3}(\mathrm{CO})_{10}\left(\mathrm{CH}_{3} \mathrm{CN}\right)_{2}\right](100 \mathrm{mg}, 0.173 \mathrm{mmol})$ and cyanoethyldiphenylphosphine $(26 \mu \mathrm{L}, 0.173$ mmol) in dry dichloromethane $(50 \mathrm{~mL})$ was taken to reflux under nitrogen for $4 \mathrm{~h}$. After evaporation of the solvent, TLC $\left(\mathrm{SiO}_{2}\right)$ of the yellow residue (dichloromethane/hexane, 6:4 v/v) 
gave $\left[\mathrm{Os}_{3}(\mathrm{CO})_{11}\left(\eta^{1}-\mathrm{PC}_{15} \mathrm{H}_{14} \mathrm{~N}\right)\right]$ (3) $(13 \%$ yield $)$ and two inseparable isomers of formula $\left[\mathrm{Os}_{3}(\mathrm{CO})_{10}\left(\eta^{1}-\mathrm{PC}_{15} \mathrm{H}_{14} \mathrm{~N}\right)_{2}\right]$ (4) $\left(28 \%\right.$ yield). Spectral data for 3: IR ( $v_{(\mathrm{CO})}$, cyclohexane): $2108 \mathrm{w}$, 2055 s, 2042 s, 2022 s, 2001 s, 1987 m, 1969 w. ${ }^{1} \mathrm{H}$ NMR (500 MHz, $\left.\mathrm{CDCl}_{3}\right): \delta=2.17\left(\mathrm{~m}, 2 \mathrm{H}, \mathrm{H}_{\beta}\right)$, $2.93\left(\mathrm{~m}, 2 \mathrm{H}, \mathrm{H}_{\alpha}\right), 7.48\left(\mathrm{~m}, 10 \mathrm{H}, \mathrm{o}-/ m-/ p-\mathrm{H}_{P h}\right) .{ }^{13} \mathrm{C}\left\{{ }^{1} \mathrm{H}\right\} \mathrm{NMR}\left(500 \mathrm{MHz}, \mathrm{CDCl}_{3}\right): \delta=13.23\left(\mathrm{~s}, \mathrm{C}_{\beta}\right)$, $32.62\left(\mathrm{~d},{ }^{1} J_{\mathrm{P}-\mathrm{C}}=31.9 \mathrm{~Hz}, \mathrm{C}_{\alpha}\right), 117.52\left(\mathrm{~d},{ }^{3} J_{\mathrm{P}-\mathrm{C}}=17.8 \mathrm{~Hz}, \mathrm{C}_{\gamma}\right), 129.27\left(\mathrm{~d},{ }^{3} J_{\mathrm{P}-\mathrm{C}}=10.4 \mathrm{~Hz}, m-\mathrm{C}_{P h}\right)$, $131.54\left(\mathrm{~d},{ }^{4} J_{\mathrm{P}-\mathrm{C}}=2.4 \mathrm{~Hz}, p-\mathrm{C}_{P h}\right), 131.62\left(\mathrm{~d},{ }^{2} J_{\mathrm{P}-\mathrm{C}}=10.4 \mathrm{~Hz}, o-\mathrm{C}_{P h}\right), 132.90\left(\mathrm{~d},{ }^{1} J_{\mathrm{P}-\mathrm{C}}=52.5 \mathrm{~Hz}\right.$, ipso- $\left.\mathrm{C}_{P h}\right), 182.84-171.83(\mathrm{M}-\mathrm{CO}) .{ }^{31} \mathrm{P}\left\{{ }^{1} \mathrm{H}\right\}$ NMR $\left(300 \mathrm{MHz}, \mathrm{CDCl}_{3}\right): \delta=-10.30$ (s). Spectral data for 4: IR ( $v_{(\mathrm{CO})}$, cyclohexane): $2088 \mathrm{w}, 2031 \mathrm{~m}, 2005 \mathrm{~s}, 1973 \mathrm{w}, 1957 \mathrm{w} .{ }^{1} \mathrm{H}$ NMR (500 MHz, $\left.\mathrm{CDCl}_{3}\right): \delta=2.15\left(\mathrm{~m}, 2 \mathrm{H}, \mathrm{H}_{\beta}\right), 2.92\left(\mathrm{~m}, 2 \mathrm{H}, \mathrm{H}_{\alpha}\right), 7.47\left(\mathrm{~m}, 10 \mathrm{H}, \mathrm{o}-/ m-/ p-\mathrm{H}_{P h}\right) .{ }^{13} \mathrm{C}\left\{{ }^{1} \mathrm{H}\right\} \mathrm{NMR}(500$ $\left.\mathrm{MHz}, \mathrm{CDCl}_{3}\right): \delta=13.14\left(\mathrm{~s}, \mathrm{C}_{\beta}\right), 32.61\left(\mathrm{~d},{ }^{1} J_{\mathrm{P}-\mathrm{C}}=27.7 \mathrm{~Hz}, \mathrm{C}_{\alpha}\right), 117.81\left(\mathrm{~d},{ }^{3} J_{\mathrm{P}-\mathrm{C}}=17.8 \mathrm{~Hz}, \mathrm{C}_{\gamma}\right)$, $129.06\left(\mathrm{~d},{ }^{3} J_{\mathrm{P}-\mathrm{C}}=10.4 \mathrm{~Hz}, m-\mathrm{C}_{P h}\right), 131.17\left(\mathrm{~s}, p-\mathrm{C}_{P h}\right), 131.67\left(\mathrm{~d},{ }^{2} J_{\mathrm{P}-\mathrm{C}}=10.1 \mathrm{~Hz}, o-\mathrm{C}_{P h}\right), 133.30(\mathrm{~d}$, ${ }^{1} J_{\mathrm{P}-\mathrm{C}}=54.8 \mathrm{~Hz}$, ipso- $\left.\mathrm{C}_{P h}\right) .{ }^{31} \mathrm{P}\left\{{ }^{1} \mathrm{H}\right\} \mathrm{NMR}\left(300 \mathrm{MHz}, \mathrm{CDCl}_{3}, 20{ }^{\circ} \mathrm{C}\right): \delta=-9.42(\mathrm{~s}),-10.47(\mathrm{~s}),-14.22$ (s).

\section{Acknowledgements}

We thank FONACIT and Laboratorio Nacional de Difracción de Rayos-X for funding the projects G-20050000447 and LAB-97000821, respectively. Additionally, we thank to the Programa de Cooperación de Post-grado (PCP) between France and Venezuela.

\section{Appendix A. Supplementary material}

CCDC 944931, 944933 and 944932 contain the supplementary crystallographic data for compounds 2b, 3 and 4a, respectively. These data can be obtained free of charge from The Cambridge Crystallographic Data Center via www.ccdc.cam.ac.uk/data_request/cif. 


\section{References}

[1] M.D. Fryzuk, Organometallics 1 (1982) 408.

[2] W.M. Alley, I.K. Hamdemir, Q. Wang, A.I. Frenkel, L. Li, J.C. Yang, L.D. Menard, R.G. Nuzzo, S. Özkar, K.A. Johnson, R.G. Finke, Inorg. Chem. 49 (2010) 8131.

[3] A.J. Sivak, E.L. Muetterties, J. Am. Chem. Soc. 101 (1979) 4878.

[4] M. Kulzick, R.T. Price, E.L. Muetterties,V.W. Day, Organometallics 1 (1982) 1256.

[5] K.-H. Yih, I.K. Hamdemir, J.E. Mondloch, E. Bayram, S. Özkar, R. Vasić, A.I. Frenkel, O.P. Anderson, R.G. Finke, Inorg. Chem. 51 (2012) 3186.

[6] J. Lewis, B.F.G. Johnson, Pure Appl. Chem. 44 (1975) 43.

[7] M.A.M. Al-Ibadi, S.B. Duckett, J.E. McGrady, Dalton Transactions 41 (2012) 4618.

[8] A.J. Deeming, S. Hasso, J. Organomet. Chem. 114 (1976) 313.

[9] S.C. Brown, J. Evans, J. Chem. Soc., Chem. Commun. (1978) 1063.

[10] S.C. Brown, J. Evans, J. Chem. Soc., Dalton Trans. (1982) 1049.

[11] J.B. Keister, J.R. Shapley, Inorg. Chem. 21 (1982) 3304.

[12] S. Aime, R. Gobetto, E. Valls, Inorg. Chim. Acta 275-276 (1998) 521.

[13] R.E. Benfield, B.F.G. Johnson, J. Lewis, P.R. Raithby, C. Zuccaro,K. Henrick, Acta Crystallogr., Sect. B: Struct. Sci 35 (1979) 2210.

[14] A.K. Ma, F.W.B. Einstein, V.J. Johnston, R.K. Pomeroy, Organometallics 9 (1990) 45.

[15] R.D. Adams, N.M. Golembeski, J. Am. Chem. Soc. 101 (1979) 2579.

[16] W. Kee Leong, Y. Liu, J. Organomet. Chem. 584 (1999) 174.

[17] D. Peña, Y. Otero, A. Arce, L. Díaz, Y. De Sanctis, E. Ocando-Mavarez, J.M. García, R. Machado, T. González, J. Organomet. Chem. 772-773 (2014) 7.

[18] A.J. Arce, Y. De Sanctis, J. Manzur, A.J. Deeming, N.I. Powell, J. Organomet. Chem. 408 (1991) C18. 
[19] A.J. Deeming, N.I. Powell, A.J. Arce, Y. De Sanctis, J. Manzur, J. Chem. Soc., Dalton Trans. (1991) 3381.

[20] A.J. Arce, Y. De Sanctis, M.C. Goite, R. Machado, Y. Otero, T. Gonzalez, Inorg. Chim. Acta $392(2012) 241$.

[21] M.R. Churchill, B.G. DeBoer, Inorg. Chem. 16 (1977) 2397.

[22] D. Blazina, S.B. Duckett, P.J. Dyson, B.F.G. Johnson, J.A.B. Lohman, C.J. Sleigh, J. Am. Chem. Soc. 123 (2001) 9760.

[23] D. Blazina, S.B. Duckett, P.J. Dyson, J.A.B. Lohman, Angew. Chem. Int. Ed. 40 (2001) 3874.

[24] D. Blazina, S.B. Duckett, P.J. Dyson, J.A.B. Lohman, Chem. Eur. J. 9 (2003) 1045.

[25] A.P. Humphries, H.D. Kaesz, Prog. Inorg. Chem. (2007) 145.

[26] L.J. Farrugia, J. Organomet. Chem. 394 (1990) 515.

[27] M.I. Bruce, B.K. Nicholson, M.L. Williams, J. Organomet. Chem. 243 (1983) 69.

[28] M.I. Bruce, J.G. Matisons, B.K. Nicholson, J. Organomet. Chem. 247 (1983) 321.

[29] M.I. Bruce, M.L. Williams, B.K. Nicholson, J. Organomet. Chem. 258 (1983) 63.

[30] N.K. Kiriakidou Kazemifar, M.J. Stchedroff, M.A. Mottalib, S. Selva, M. Monari, E. Nordlander, Eur. J. Inorg. Chem. 2006 (2006) 2058.

[31] A. Thapper, E. Sparr, B.F.G. Johnson, J. Lewis, P.R. Raithby, E. Nordlander, Inorg. Chem. Commun. 7 (2004) 443.

[32] A.J. Deeming, B.F.G. Johnson, J. Lewis, J. Chem. Soc. A (1970) 897.

[33] A.J. Deeming, S. Donovan-Mtunzi, S.E. Kabir, P.J. Manning, J. Chem. Soc., Dalton Trans. (1985) 1037.

[34] J.R. Shapley, J.B. Keister, M.R. Churchill, B.G. DeBoer, J. Am. Chem. Soc. 97 (1975) 4145.

[35] R.F. Alex, R.K. Pomeroy, Organometallics 6 (1987) 2437.

[36] R.W. Broach, J.M. Williams, Inorg. Chem. 18 (1979) 314. 
[37] V.M. Hansen, A.K. Ma, K. Biradha, R.K. Pomeroy, M.J. Zaworotko, Organometallics 17 (1998) 5267.

[38] K. Biradha, V. Hansen, W. Leong, R. Pomeroy, M. Zaworotko, J. Cluster Sci. 11 (2000) 285.

[39] Y. Otero, D. Peña, Y. De Sanctis, A. Arce, E. Ocando-Mavarez, R. Machado, T. Gonzalez, Transition Met. Chem. 39 (2014) 239.

[40] H.D. Kaesz, S.A.R. Knox, J.W. Koepke, R.B. Saillant, J. Chem. Soc., Chem. Commun. (1971) 477.

[41] J.N. Nicholls, M.D. Vargas, A.J. Deeming, S.E. Kabir, Inorg. Synth. (2007) 289.

[42] C. Hay, M. Hissler, C. Fischmeister, J. Rault-Berthelot, L. Toupet, L. Nyulászi, R. Réau, Chem. Eur. J. 7 (2001) 4222.

[43] M. Habib, H. Trujillo, C.A. Alexander, B.N. Storhoff, Inorg. Chem. 24 (1985) 2344.

[44] M.M. Rauhut, I. Hechenbleikner, H.A. Currier, F.C. Schaefer, V.P. Wystrach, J. Am. Chem. Soc. 81 (1959) 1103.

[45] Z. Rohlík, P. Holzhauser, J. Kotek, J. Rudovský, I. Němec, P. Hermann, I. Lukeš, J. Organomet. Chem. 691 (2006) 2409. 
Table 1. Rate constants $(k c)$ and free energies of activation $\left(\Delta G_{\mathrm{c}}^{\dagger}\right)$ for the dynamic processes in 1a,c and $\mathbf{2 c}$.

\begin{tabular}{ccc}
\hline Process & $k \mathrm{c}\left(\times 10^{3} \mathrm{~s}^{-1}\right)$ & $\left.\Delta G_{\mathrm{c}}^{\ddagger}(\mathrm{kcal} \mathrm{mol})^{-1}\right)$ \\
\hline $1 \mathrm{a}_{\mathrm{HB}} \rightarrow 1 \mathrm{a}_{\mathrm{HT}}$ & 10.8 & 12.2 \\
$1 \mathrm{c}_{\mathrm{HB}} \rightarrow 1 \mathrm{c}_{\mathrm{HT}}$ & 6.0 & 14.9 \\
$2 \mathrm{c}^{1}{ }_{\mathrm{HB} 1} \rightarrow 2 \mathrm{c}^{2}{ }_{\mathrm{HB} 1}$ & 0.03 & 18.5 \\
$2 \mathrm{c}^{1}{ }_{\mathrm{HB} 2} \rightarrow 2 \mathrm{c}^{2}{ }_{\mathrm{HB} 2}$ & 0.02 & 18.7 \\
$2 \mathrm{c}^{1}{ }_{\mathrm{HB} 1} \rightarrow 2 \mathrm{c}^{2}{ }_{\mathrm{HB} 2}$ & 2.2 & 15.6 \\
$2 \mathrm{c}^{1}{ }_{\mathrm{HB} 2} \rightarrow 2 \mathrm{c}^{2}{ }_{\mathrm{HB} 1}$ & 2.2 & 15.6 \\
$2 \mathrm{c}^{1}{ }_{\mathrm{HB} 1} \rightarrow 2 \mathrm{c}^{3}{ }_{\mathrm{HB}}$ & 3.3 & 15.3 \\
$2 \mathrm{c}^{1}{ }_{\mathrm{HB} 2} \rightarrow 2 \mathrm{c}^{3}{ }_{\mathrm{HB}}$ & 1.1 & 16.1 \\
$2 \mathrm{c}^{1}{ }_{\mathrm{HB} 1} \rightarrow 2 \mathrm{c}^{4}{ }_{\mathrm{HB}}$ & 4.0 & 15.2 \\
$2 \mathrm{c}^{1}{ }_{\mathrm{HB} 2} \rightarrow 2 \mathrm{c}^{4}{ }_{\mathrm{HB}}$ & 1.8 & 15.8 \\
$2 \mathrm{c}^{2}{ }_{\mathrm{HB} 1} \rightarrow 2 \mathrm{c}^{3}{ }_{\mathrm{HB}}$ & 3.3 & 15.3 \\
$2 \mathrm{c}^{2}{ }_{\mathrm{HB} 2} \rightarrow 2 \mathrm{c}^{3}{ }_{\mathrm{HB}}$ & 1.1 & 16.1 \\
$2 \mathrm{c}^{2}{ }_{\mathrm{HB} 1} \rightarrow 2 \mathrm{c}_{\mathrm{HB}}^{4}$ & 4.0 & 15.1 \\
$2 \mathrm{c}_{\mathrm{HB} 2}^{2} \rightarrow 2 \mathrm{c}^{4}{ }_{\mathrm{HB}}$ & 1.8 & 15.8 \\
$2 \mathrm{c}^{3}{ }_{\mathrm{HB}} \rightarrow 2 \mathrm{c}_{\mathrm{HB}}$ & 0.7 & 16.4 \\
\hline
\end{tabular}

Table 2. Selected bond lengths $(\AA)$ and angles $\left(^{\circ}\right)$ for compound $\mathbf{2 b}$.

\begin{tabular}{cccc}
\multicolumn{4}{c}{$\left[\mathrm{Os}_{3}(\mathrm{CO})_{9}(\mu-\mathrm{H})_{2}\left(\eta^{1}-\mathrm{PC}_{26} \mathrm{H}_{23}\right)\right](\mathbf{2 b})$} \\
\hline Os1 - Os2 & $2.691(3)$ & $\mathrm{P} 1-\mathrm{Os} 1-\mathrm{Os} 2$ & $104.8(1)$ \\
Os1 - Os3 & $2.804(5)$ & $\mathrm{Os} 1-\mathrm{Os} 2-\mathrm{C} 23 \mathrm{~A}$ & $110.0(5)$ \\
Os2 - Os3 & $2.819(3)$ & $\mathrm{P} 1-\mathrm{Os} 1-\mathrm{Os} 3$ & $165.8(5)$ \\
$\mathrm{P} 1-\mathrm{Os} 1$ & $2.355(5)$ & & \\
\hline
\end{tabular}

Table 3. Selected bond lengths $(\AA)$ and angles $\left(^{\circ}\right)$ for compounds $\mathbf{3}$ and $\mathbf{4 a}$.

\begin{tabular}{cc|cc}
\hline$\left[\mathrm{Os}_{3}(\mathrm{CO})_{11}\left(\eta^{1}-\mathrm{PC}_{15} \mathrm{H}_{14} \mathrm{~N}\right)\right](\mathbf{3})$ & \multicolumn{2}{|c}{$\left[\mathrm{Os}_{3}(\mathrm{CO})_{10}\left(\eta^{1}-\mathrm{PC}_{15} \mathrm{H}_{14} \mathrm{~N}\right)_{2}\right] \mathbf{( 4 a )}$} \\
\hline Os1-Os2 & $2.9205(18)$ & Os1-Os2 & $2.8967(5)$ \\
Os1-Os3 & $2.8950(18)$ & $\mathrm{O} 1-\mathrm{Os} 3$ & $2.8755(5)$ \\
Os2-Os3 & $2.886(2)$ & $\mathrm{Os} 2-\mathrm{Os} 3$ & $2.9018(5)$ \\
Os2-P1 & $2.349(6)$ & $\mathrm{Os} 1-\mathrm{P} 1$ & $2.355(2)$ \\
$\mathrm{N} 1-\mathrm{C} 15$ & $0.98(7)$ & $\mathrm{Os} 3-\mathrm{P} 2$ & $2.340(2)$ \\
& & $\mathrm{N} 1-\mathrm{C} 15$ & $1.10(2)$ \\
Os3-Os1-Os2 & $59.51(5)$ & $\mathrm{N} 2-\mathrm{C} 30$ & $1.15(2)$ \\
Os3-Os2-Os1 & $59.80(5)$ & $\mathrm{Os} 1-\mathrm{Os} 2-\mathrm{Os} 3$ & $59.459(10)$ \\
Os2-Os3-Os1 & $60.68(3)$ & $\mathrm{Os} 3-\mathrm{Os} 1-\mathrm{Os} 2$ & $60.359(12)$ \\
$\mathrm{P} 1-\mathrm{Os} 2-\mathrm{Os} 1$ & $104.24(15)$ & $\mathrm{Os} 1-\mathrm{Os} 3-\mathrm{Os} 2$ & $60.182(11)$ \\
$\mathrm{P} 1-\mathrm{Os} 2-\mathrm{Os} 3$ & $163.87(14)$ & $\mathrm{P} 1-\mathrm{Os} 1-\mathrm{Os} 3$ & $163.35(5)$ \\
& & $\mathrm{P} 2-\mathrm{Os} 3-\mathrm{Os} 1$ & $164.98(5)$ \\
\hline
\end{tabular}




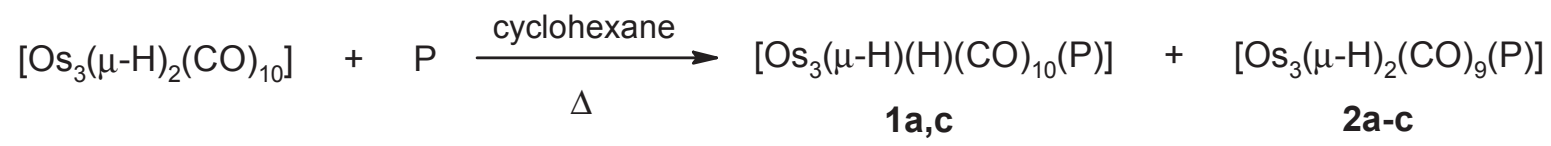

$$
\begin{aligned}
& P=C_{R}^{P-P h}, R=2-\text { thienyl }(\mathbf{a}), P h(b), 2-P y(c)
\end{aligned}
$$

Scheme 1. Reaction of $\left[\mathrm{Os}_{3}(\mu-\mathrm{H})_{2}(\mathrm{CO})_{10}\right]$ with phospholes derivatives. 


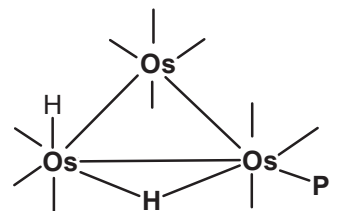

$1 c$

a)

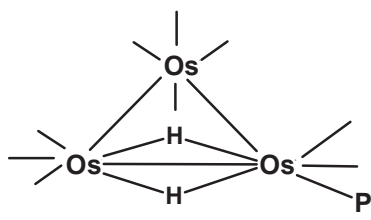

$$
2 c^{2}
$$

P-pseudoaxial

b)

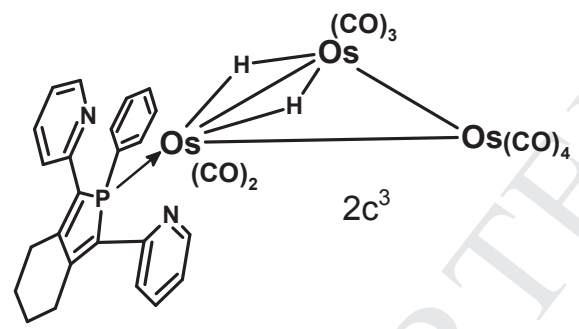

"downward"

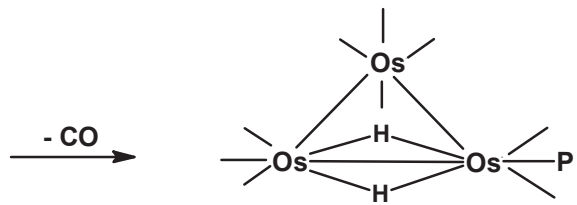

$2 c^{3-4}$

P-equatorial
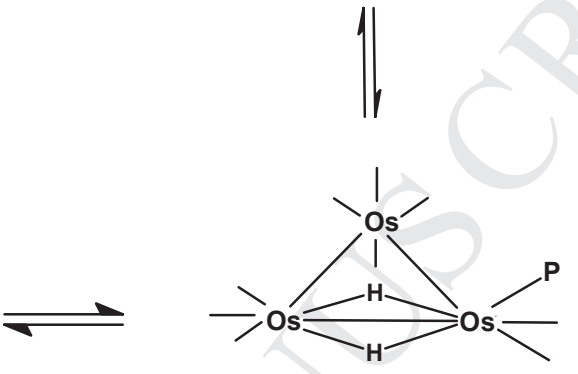

$2 c^{1}$

P-pseudoaxial
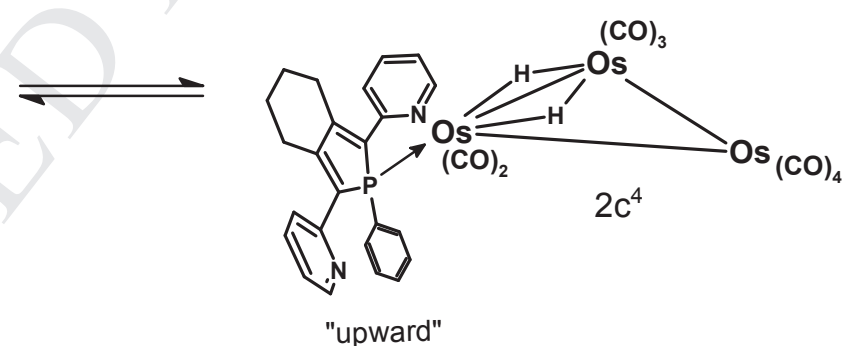

Scheme 2. a) Formation and proposed fluxional behavior of $2 \mathbf{c}$. b) Fluxional equilibrium between the isomers $2 c^{3}$ and $2 c^{4}$. 


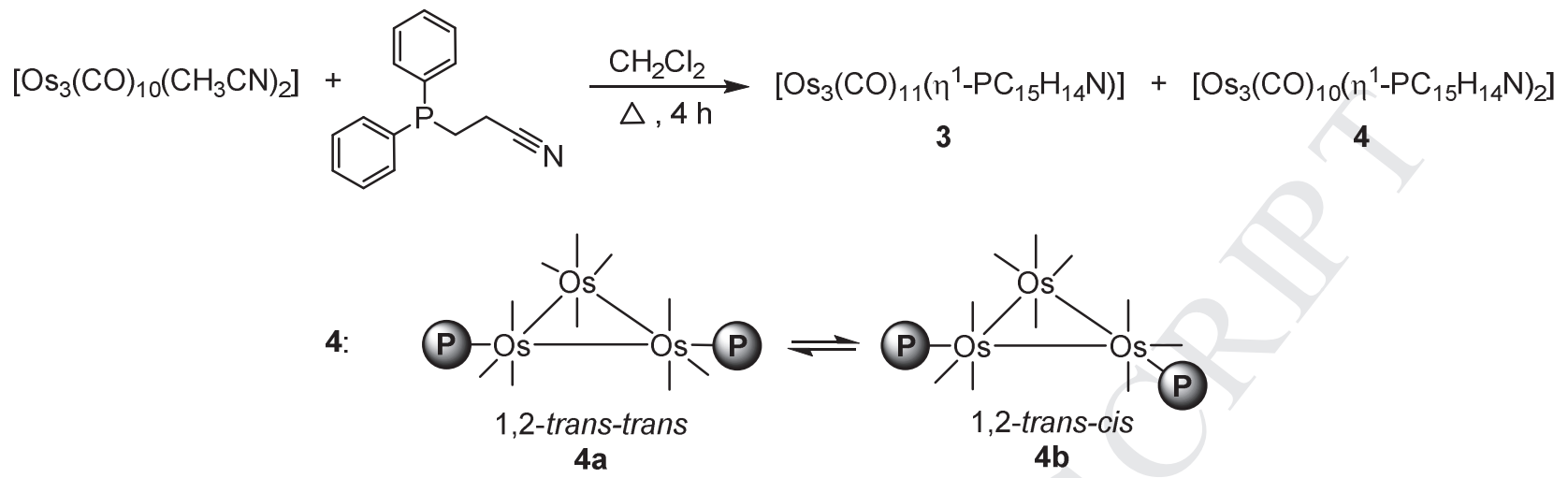

Scheme 3. Reaction of $\left[\mathrm{Os}_{3}(\mathrm{CO})_{10}\left(\mathrm{CH}_{3} \mathrm{CN}\right)_{2}\right]$ with cyanoethyldiphenylphosphine. 
$T=20$

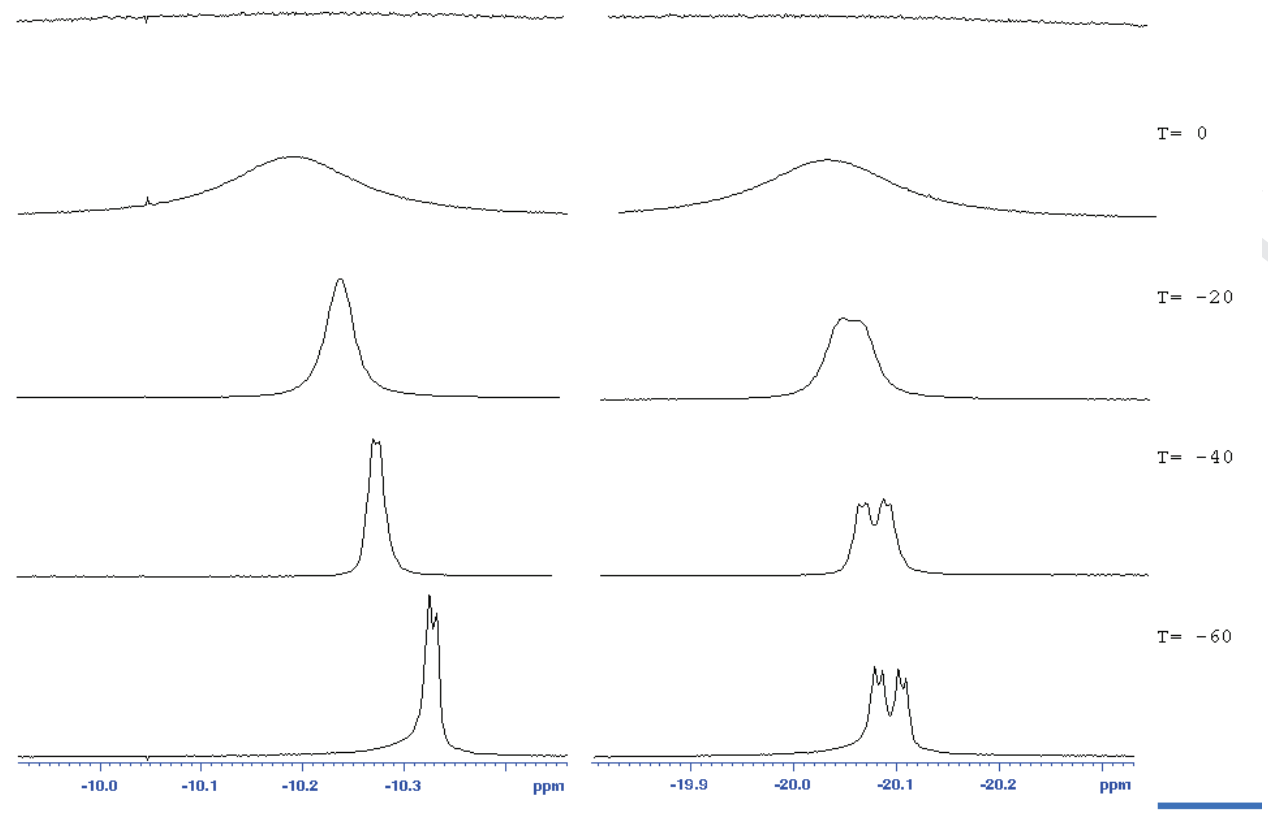

Figure 1. Variable-temperature ${ }^{1} \mathrm{H}$ NMR spectra of the hydride region of $\mathbf{1 a}$ in $\mathrm{CD}_{2} \mathrm{Cl}_{2}$ 

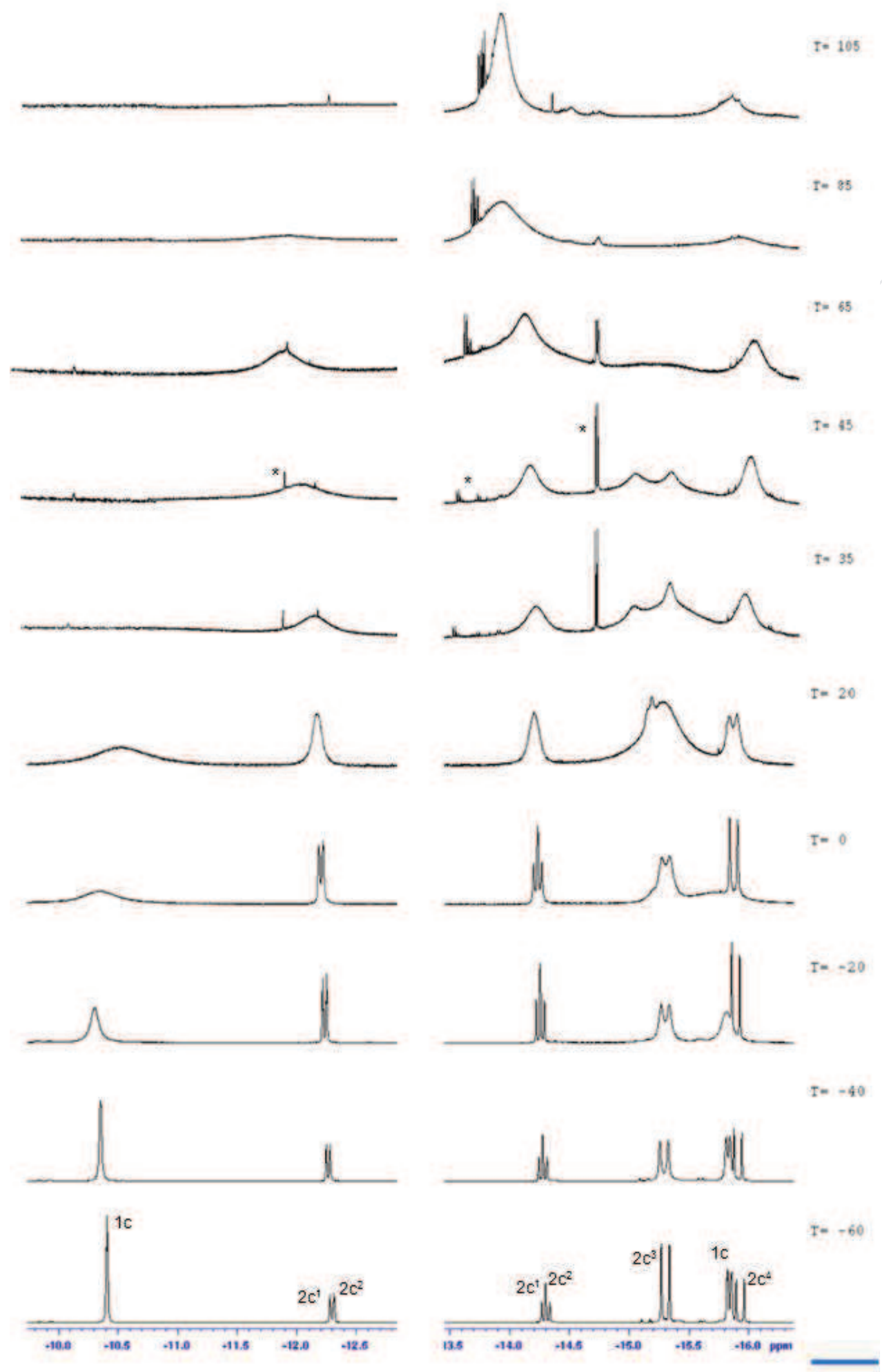

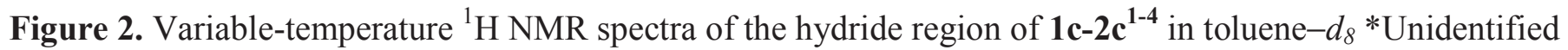
compounds. 


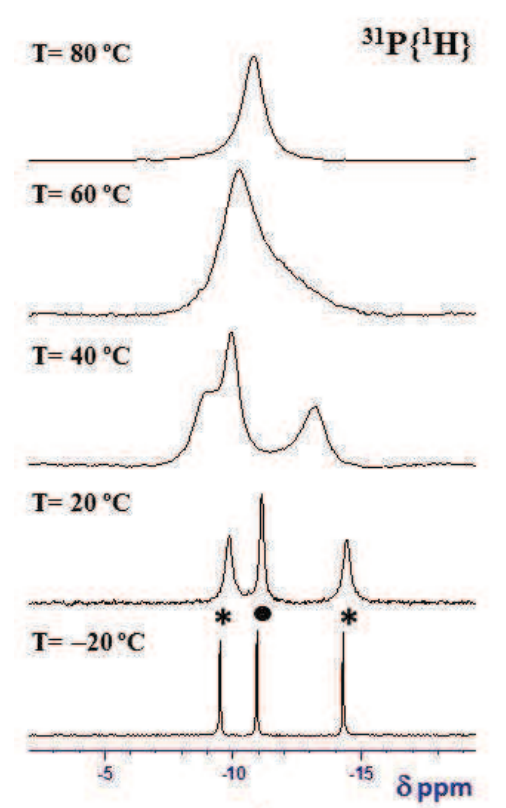

a)

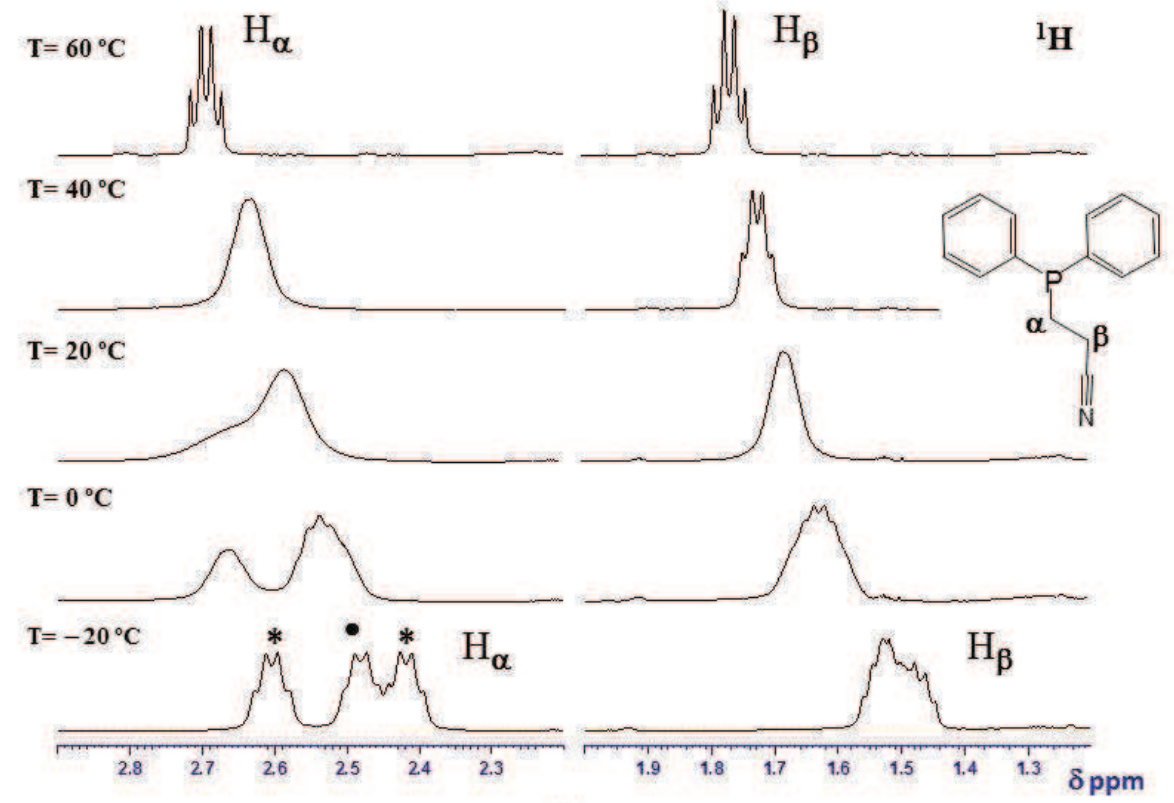

b)

Figure 3. Variable-Temperature NMR spectra of 6 in toluene- $d_{8}:$ a) ${ }^{31} \mathrm{P}\left\{{ }^{1} \mathrm{H}\right\}$ and b) ${ }^{1} \mathrm{H}$ of the alkyl group region. * 1,2-trans-cis Isomer and • 1,2-trans-trans Isomer 


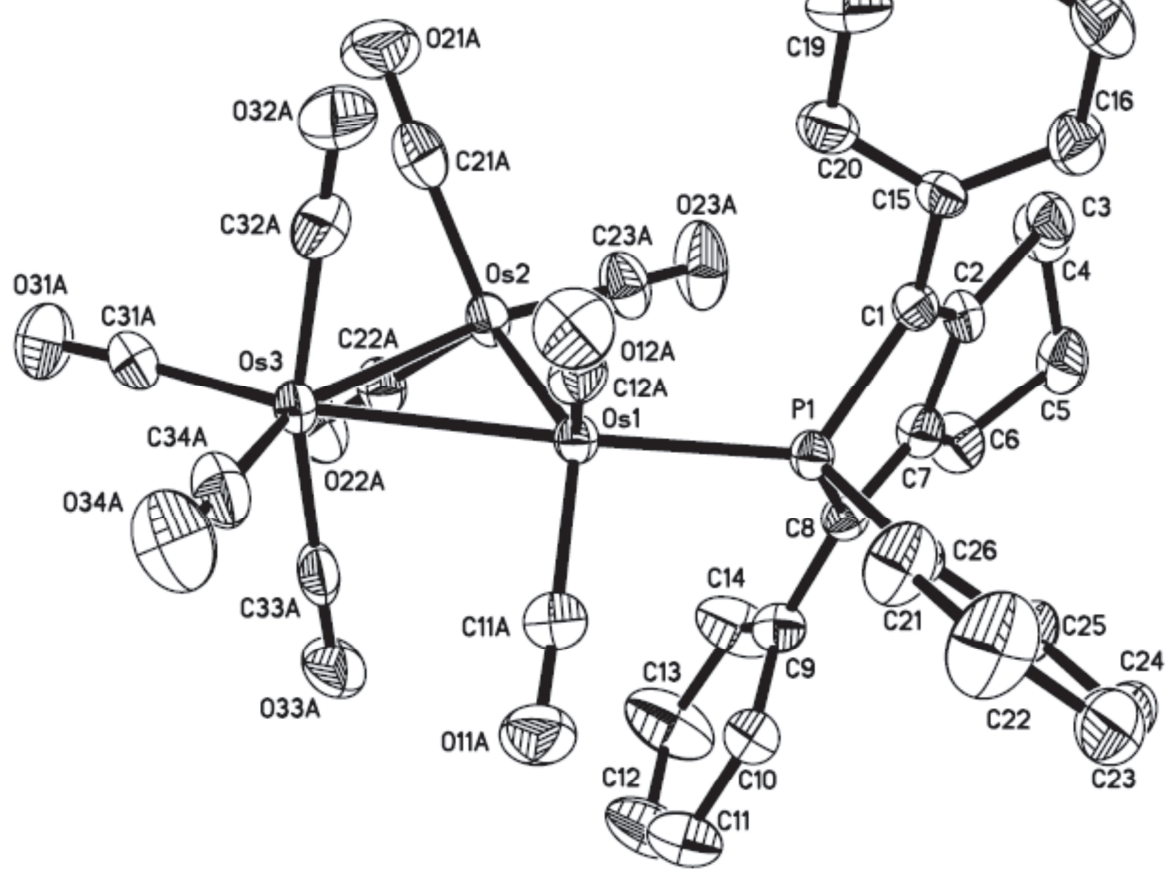

Figure 4. Molecular structure of $\mathbf{2 b}$, showing 50\% probability ellipsoids. 


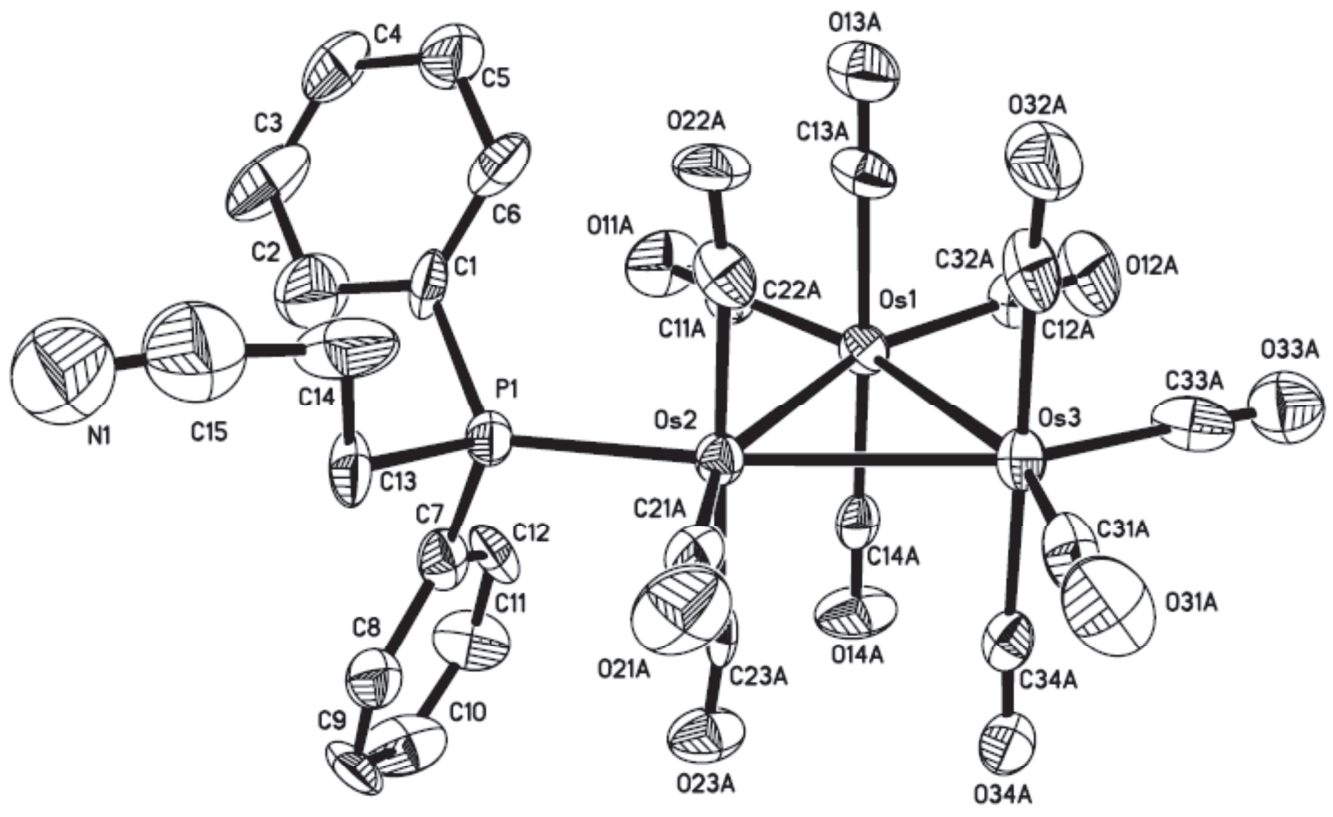

Figure 5. Molecular structure of $\mathbf{3}$, showing 50\% probability ellipsoids. 


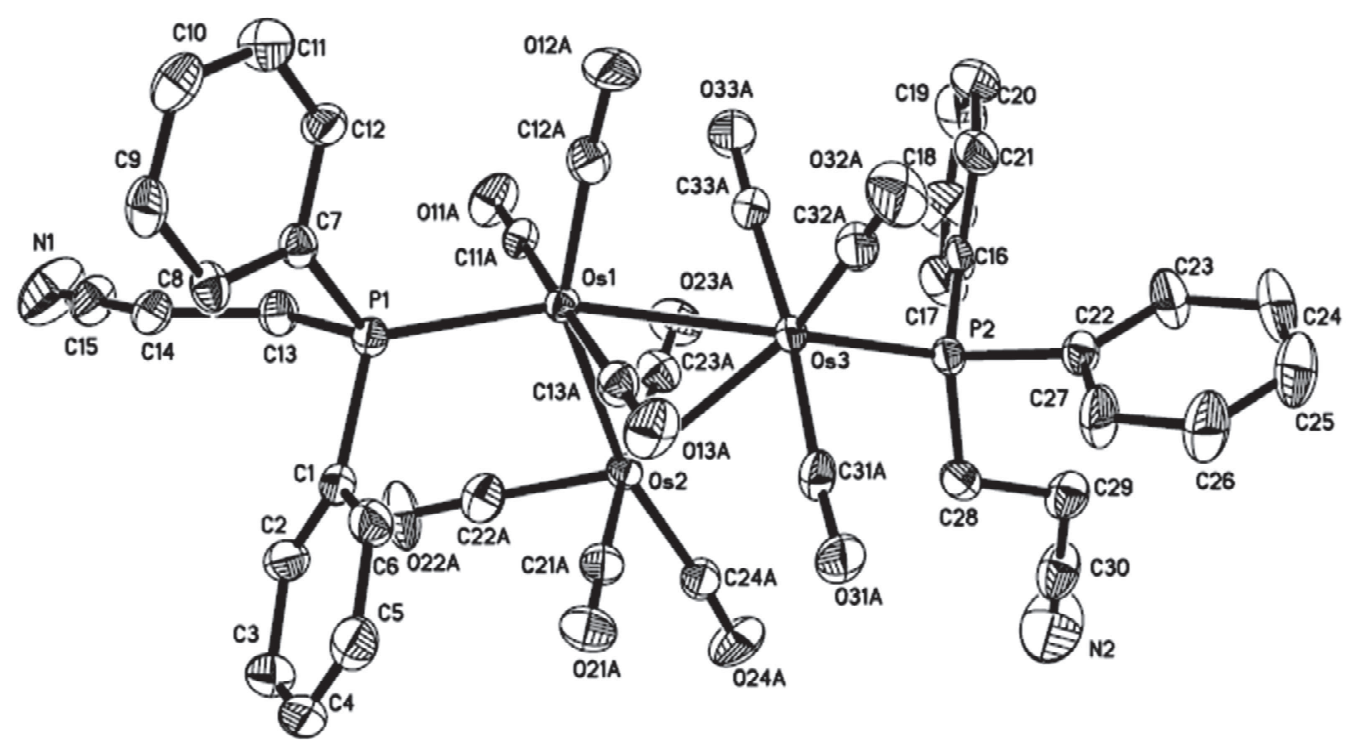

Figure 6. Molecular structure of $\mathbf{4 a}$, showing $50 \%$ probability ellipsoids. 
The hydride ligands in $\left[\mathrm{Os}_{3}(\mu-\mathrm{H})(\mathrm{H})(\mathrm{CO})_{10}\right.$ (phosphole) $]$ (A) undergo fluxional behavior.

Decarbonylation of $\mathbf{A}$ gives nonacarbonyl unsaturated species with equivalent hydrides.

Mono- and bis-substituted osmium clusters are obtained with phosphine ligands.

$\left[\mathrm{Os}_{3}(\mathrm{CO})_{10}(\mathrm{P})_{2}\right]$ exist as a mixture of 1,2-trans-trans and 1,2-cis-trans isomers. 